\title{
A Review of Performance-Oriented Architectural Design and Optimization in the Context of Sustainability: Dividends and Challenges
}

\author{
Shaoxiong $\mathrm{Li}^{1}{ }^{1}$, Le Liu $^{1}$ and Changhai Peng ${ }^{1,2, *}$ \\ 1 School of Architecture, Southeast University, Nanjing 210096, China; 230159310@seu.edu.cn (S.L.); \\ 220180022@seu.edu.cn (L.L.) \\ 2 Key Laboratory of Urban and Architectural Heritage Conservation (Southeast University), Ministry of \\ Education, Nanjing 210096, China \\ * Correspondence: pengchanghai@seu.edu.cn; Tel.: +86-25-8379-2484 or 138-5168-2989; Fax: +86-25-8379-3232
}

Received: 30 December 2019; Accepted: 12 February 2020; Published: 14 February 2020

Abstract: As most countries have widespread and growing concerns about the sustainable development of society, the requirement to continuously reduce energy consumption poses challenges for the architecture, engineering and construction (AEC) industry. Performance-oriented architectural design and optimization, as a novel design philosophy and comprehensive evolution technology, has been accepted by architects, engineers, and stakeholders for a period of time. Performance in the context of architecture is a widely discussed definition that has long shown a correlation with visual and cultural attributes. Shifting the paradigm of sustainable development while ensuring that the function and aesthetics of the building are not overlooked has been the focus of public attention. Considering the core design elements that affect energy conservation and style performance, the design and optimization of building envelopes, form, and shading systems were selected as research materials. From the perspective of epistemology and methodology, a systematic review of 99 papers was conducted to promulgate the latest development status of energy-efficiency design. This paper manifests a detailed analysis of the design patterns, research features, optimization objectives, and techniques of current approaches. The review found that performance-oriented design optimization can benefit the entire industry from the heuristic knowledge base and the expansion of the design space while maintaining sustainability. In contrast, challenges such as tools, skills, collaboration frameworks, and calibration models are highlighted.

Keywords: performance-oriented; sustainable architecture; building envelope; building form; shading system; design and optimization; AEC industry

\section{Introduction}

\subsection{Background}

In the context of a broad scope of architectural dialogues, the concept of performance is a particularly prominent and lasting one [1]. Aesthetic and cultural expression has long been the focus of architectural design. Theorists and practitioners are committed to ensuring that a building reveals the unique attributes of its visual aesthetic from all aspects of form, space, order, color, and detail [2]. But the overall context of building performance is highly dynamic. It is defined as a concept that describes a building's ability to perform its tasks and functions, the degree of construction control over the delivery process, and its success as a presentation or entertainment. There are various trends in the architecture, engineering and construction (AEC) industry which are affected by performance requirements. In addition, it also maps the complexity of the research area [3]. With the 
energy crisis and the rapid deterioration of global climate and environment, for the long-term and sustainable development of human society has become the primary problem of all countries in the world [4]. With such an urgent agenda, the energy efficiency of buildings and even cities has become an unavoidable topic for architects, planners, engineers, and other stakeholders.

Research and practice in the domain of building energy performance has become the mainstream and launched Web of Science to conduct a keyword-based search of articles and abstracts in related research areas (Figure 1). Building energy performance is considered as the keyword. Records indicate that the earliest work came from 1976. The number has gradually increased since 1990 and has changed drastically in the last decade. Correspondingly, the evaluation system of building sustainability emerges in the world. A comprehensive building performance assessment method was released in the UK in 1990 (BREEAM), and the latest version was released in 2014 [5]. LEED (USA) certification standards were issued in 1998 [6]. Followed by CASBEE (Japan), GreenStar (Australia), HQE (France), and DGNB (Germany) [7]. China's Ministry of Housing and Urban-Rural Development (MOHURD) issued the first green building standard in 2006 and updated it in 2019 [8]. A large number of well-known tools are used during the design phase to help practitioners calculate, simulate, and evaluate building energy consumption [9]. In a sense, especially in the last two decades, it has witnessed a shift in the architecture, engineering and construction (AEC) industry to a sustainable era.

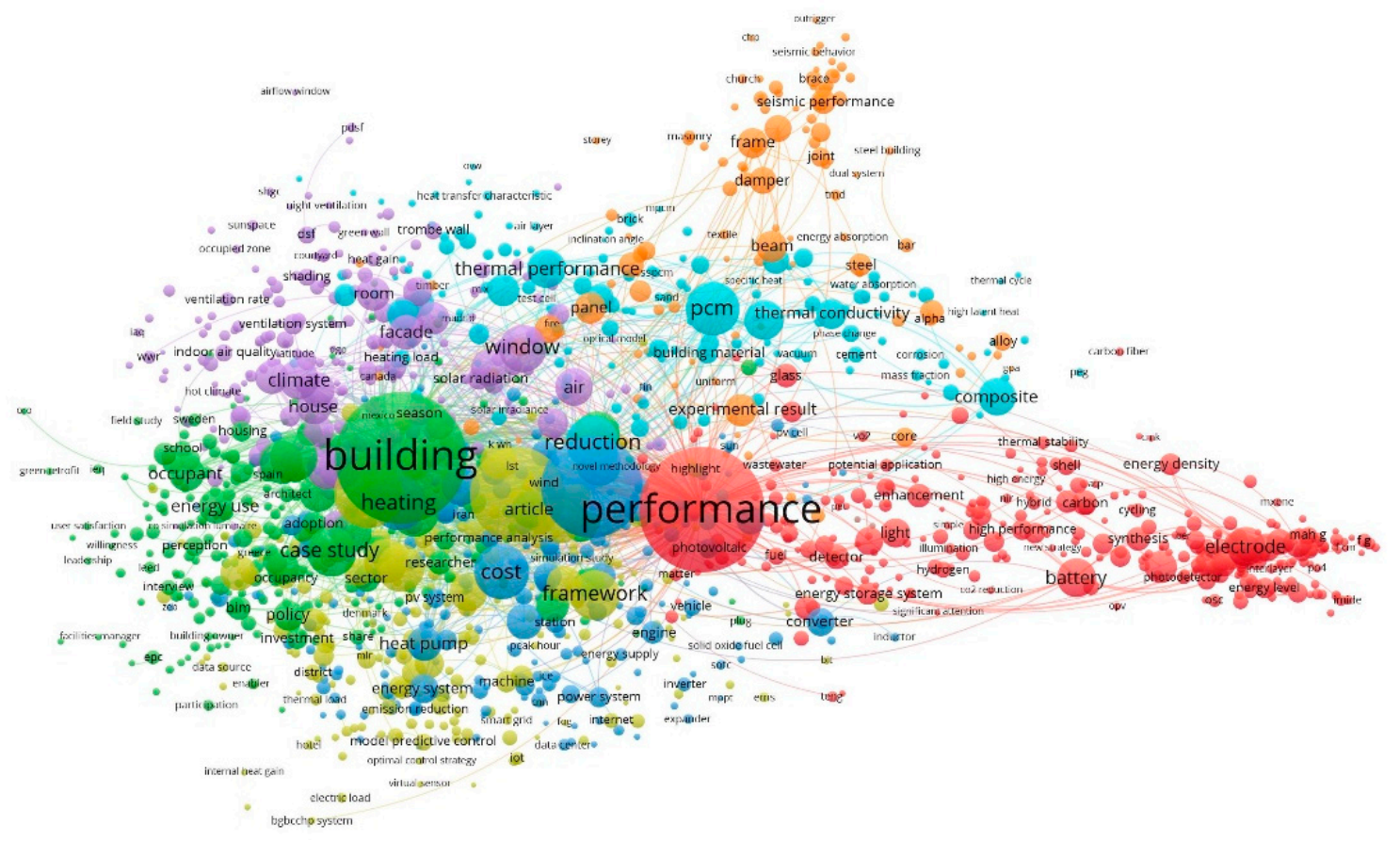

Figure 1. Keywords for building energy performance related issues.

Combining design with the natural environment, technologies, or methods aimed at optimizing efficiency in the starting chapters of work are constantly mentioned. Professional terms such as "performance-based design" and "performance-driven design" are considered a new design philosophy [10]. Review the development history of regional architectural practice in the "pre-tech" era. Environmental characteristics have proven to be an important influencing factor in architectural expression. There is a significant relationship between the specific characteristics of the building and its climate region. It is not just a coincidence that groups of different faiths and cultures have found solutions between creative building activities and the climate in which they live [11]. At the same time, the voice of doubt followed. Too much attention to whether building energy efficiency will lead to the lack of traditional design aesthetics will inevitably cause anxiety. Interestingly, some scholars believe that most of the components that affect the energy structure of buildings contribute little to the style 
and visual characteristics associated with contemporary architecture [12]. Strictly speaking, this is not just a debate on design methodology. A re-examination of all doubts has revealed deeper concerns. Extensive multidisciplinary cooperation and the growth of the technical team have indeed brought about improvements in efficiency and quality. However, the concept of openness and the lack of a clear consensus on the operation mode could lead to deviation and incompatibility.

\subsection{Hypotheses and Purposes of the Work}

The main task of this review is to carry out a systematic and quantitative study of energy optimization methods and experiments in the initial stage with a focus on reviewing and analyzing the latest technologies from the perspective of design decision makers. The reasons for the resolution are listed as follows: First and foremost, unlike pure visual design art, architectural design is a comprehensive discipline that combines personal preferences and rational logic. With the energy consumption targets in the list becoming the top priority, the workload of various categories has increased significantly. Compared with the traditional graphic language, how to deal with the data-based design method is a new problem faced by architects. Secondly, the professional skills required of architects are more stringent than in any previous period, and there can be subtle tradeoffs in design aesthetics and instrumental rationality. Last but not least, the complexity of the building system requires different professionals in the technical team to work together in the workflow, which is essentially different from the previous work mode. Architecture and energy provide architects and building theorists with more lasting arguments for environmental design decisions. The hypotheses involved in sustainable design are that the way in which energy is used can be transformed (directly or indirectly) into the visible aspects of architectural styles and their specific forms. In other words, different "performance" synergies are implemented in the optimization process. In summary, the purpose of this review is to collect and analyze relevant literature, and discuss the actual benefits and potential conflicts of performance-oriented building design and optimization in the context of sustainability.

\subsection{Scope and Specifications}

Web of Science and ScienceDirect were used to conduct a global search for related journals and conference papers. The keywords included "building", "performance", "energy consumption", "design", and "optimization". Various combinations of the mentioned keywords were made. The final inclusion deadline for all works was from 1990 to 2019. Nevertheless, the number of articles accessed was still enormous. The purpose of this paper is to explore the implicit relevance between energy performance-oriented optimization design and architectural form and style innovation. Therefore, in the further stage of literature selection, several restrictions were added:

- Whether to minimize energy cost as the driving force at the beginning stage is the first and crucial factor in screening. The thesis must clearly indicate the energy consumption benefits brought by the design or optimization scheme. Under this prerequisite, the research content must contain intuitive visual elements or style features to make it a unique architectural design vocabulary. Suppose a research paper aims to reduce all energy-related expenditures of a building and provide inspirational design knowledge to stakeholders, obviously it is considered the core content.

- If the research materials use building shapes or envelopes to expand the potential of solar energy, then, it is qualified. In addition, research topics include thermal comfort, carbon emissions, and life-cycle costs, all of which meet standards because they also contribute to sustainable development.

- Energy consumption optimization based on building material details is undoubtedly a complex and decisive research field. Herein, the main interest is how the principles of appearance and form variations affect the energy use of buildings. In addition, reference studies evaluated the impact of geometric changes and material considerations on building energy consumption. The results 
show that the sensitivity of material properties and geometric factors depends on the specific design goals. The local sensitivity index of the design variable of the geometric pattern under specific project types and climatic conditions is even higher than the material characteristics [13]. With due consideration of the existing workflow, the lag of the complete material list in the initial stage is inevitable.

- Research on the energy performance of HVAC systems and GSHP systems is not considered as valid information because the energy system cannot be classified as a distinctive architectural decoration style feature. By the same token, studies of building reconstruction or retrofit that are absent from the design process are also considered to be inconsistent with the scope of this discussion.

- Works that primarily focus on comparing and evaluating optimization algorithms, designing platforms, and frameworks, and simulation models are likewise excluded. It must be acknowledged that the validity and effectiveness of designing platforms and simulation experimental models is a significant research topic [14-16]. The research on the accuracy and robustness of energy-saving optimization algorithms is also an influential research direction.

\subsection{Previous Reviews}

Prior to this, energy-oriented building-optimized design has become a hot area. Related research work has been mentioned many times. R. Pacheco et al. [17] reviewed design criteria related to residential heating and cooling energy consumption. R. Evins [18] reviewed issues associated to the application of calculations to sustainable design and predicted research trends. V. Machairas et al. [19] investigated novel algorithms and demonstrated their characteristics and capabilities. V.S.K.V. Harish and A. Kumar [20] summarized and classified various important methods for building energy system modeling developed in recent years. T. Østergård et al. [21] studied the statistical methods based on energy consumption, proposed a decision framework, and explored the possibility of interaction between CAD software. X. Shi et al. [22] analyzed the core literature from the perspective of the architect to reveal the current status of energy-saving design of buildings, affirming that optimization design is a promising technology. K. Amasyali and N.M.E. Gohary [23] introduced the application scope, characteristics, and processing methods of building energy prediction models. X. Shi et al. [24] explained the specific reason for the gap between the performance figures predicted during the design phase and the actual results during the use phase. Z.C. Tian [25] conducted a questionnaire survey on potential obstacles to building energy efficiency simulation and optimization technology, and classified the general procedures of the technology based on the survey results.

In addition, there are some research materials that are indirectly related to this review. They focus on dynamic simulation models for sustainable building design $[26,27]$, indispensable simulation tools in the design process [28-31], and computer-based optimization methods [32-34].

\section{Performance-Oriented Design and Optimization}

Sustainable building design means seeking a global balance between reducing nonrenewable energy sources and controlling negative environmental impacts. Extensive research has found that different types of building components and systems contribute to energy conservation and emissions reduction in multiple ways. Among these categories, the design variables (even colors) associated with building physics, specifically the building envelope, form, and shading system, affect both energy performance and indoor comfort to a considerable extent [34,35]. As a discipline between art and science, the knowledge gained by architecture in dealing with different climate background problems is not only a scientific achievement, but also a cultural metaphor in creative exploration [36]. Building envelopes, forms, and shading systems are elemental catalogues that enable an equation to be established between environmental factors and building graphics. These derivable components can drive static or dynamic changes in the building and are the syntax that forms the response mechanism between environmental conditions and design solutions [37]. 


\subsection{Envelopes}

Envelopes are the boundaries and barriers of internal and external spaces to block negative factors in the environment to meet lower energy consumption and comfort. Directly related to the energy optimization of the building envelope is the screening and sequencing of the design scheme and its thermal parameters. E. Ghisi and J. Tinker [38] minimized energy consumption by capturing the best window area using digital analysis techniques. M. Košira et al. [39] defined five simplified baseline models in central European climate conditions. The best energy-saving solution was found by dynamically searching the building's window area and azimuth. L.W. Wen et al. [40] created a default value assignment map that served the early performance design phase and assisted architects to obtain effective simulation data of office buildings in various regions of Japan. M. Trebilcock et al. [41] examined school buildings in the representative climate of Chile and extracted important passive strategic design parameters. On the basis of a dynamic simulation of a multivariable combination classroom prototype, it was found that the glass area was not directly related to heating demand. V.Ž. Leskovar and M. Premrov [42] developed a measure for acquiring the energy efficiency of prefabricated wood-frame residential buildings using exterior walls with different thermal properties as independent variables and found that there is convergence between the window area and the annual energy demand. E.A. Krieteyer et al. [43] designed a dynamic glass curtain wall system. By switching the form of pixel array of movable louvers, visual visibility was maintained while reducing the invasion of sunlight. C. Hachem and M. Elsayed [44] conducted a comparative study on the innovative design of multistory office buildings. An irregular saw-tooth-shaped epidermal cell was designed. The overall performance was optimized by controlling the balance of cooling and heating loads. C. Hachem [45] designed a folded plate façade system based on previous concepts. The complex geometry shown did not affect the building but observed great potential in photovoltaic power generation applications. Digital software with friendly, customizable user interfaces is increasingly popular with architects and provides more possibilities for exploring parameterized building performance design [46]. A.X. Zhang et al. [47] took Chinese school buildings in cold climate as the research object and investigated multiple combinations between different spatial configurations and facade design parameters. The strength Pareto evolutionary algorithm was introduced to achieve a compromise between energy consumption and indoor comfort. A. Toutou et al. [48] explored the possibility of parametric modeling methods in the sustainable design of residential buildings. A variety of room fenestrations were tried, with EUI (energy use intensity) and SDA (spatial daylight autonomy) as evaluation indicators. The Pareto curve formed contained all the optimal genomes. K.B. Lauridsen and S. Petersen [49] explored a performance-based conceptual design paradigm for facades. The developed parametric information system automatically generated a series of curtain wall design solutions based on the expected standards of indoor climate, daylight, and energy performance defined by the technicians. D.A. Chi et al. [50] designed a double curtain wall for office buildings. The perforated solar screens placed were subjected to a matrix change of 16 different shapes and perforation rates, and the preferred solution balanced daylight availability and total annual energy consumption.

The effectiveness and efficiency of conventional scenario-by-scenario calculations and manual control of multiobjective optimization methods are limited by the breadth of design and the professional skills of the participants [51]. Advances in artificial intelligence technology have opened up new possibilities in the design process and the way of interaction. With the help of genetic algorithm, researchers have carried out a series of design experiments on the optimal size of building windows under specific climate conditions to improve the building's energy efficiency [52,53]. K. Negendahl and T.R. Nielsen [54] presented a holistic folded facade design process. The self-shading mechanism generated by the folding amplitude of the facade module regulated multiple optimization objectives. J. Wright and M. Mourshed [55] described a window element design that divided the building envelope into rectangular grids. The adopted algorithm constrained the design variables of the window, which could effectively improve energy saving. E.J. Glassman and C. Reinhart [56] showed innovative ways to customize building components or shapes by defining the building elements on the 
exterior wall as variables. Linked simulation tools and algorithm technologies increased the design's climate adaptability. N. Delgarm et al. [57] proposed a design measure based on artificial bee colony $(\mathrm{ABC})$ algorithm. The introduced optimization program helped expand a large number of feasible configurations regarding the glass area and the room rotation angle. G. Rapone and O. Saro [58] modeled a typical facade of an office building and based on the dynamic simulation engine and the PSO algorithm, the design parameters that affect the thermal performance such as glass percentage were searched automatically. The optimized design results of each façade are discussed.

It must be recognized that in the actual optimization problem, there is a certain probability of mismatch between the targets. When a set of uniquely designed concepts are no longer applicable, a more robust multi-criteria optimization decision is needed [59]. C. E. Ochoa et al. [60] proposed an acceptance threshold to avoid conflicts between building energy and visual dynamics. The introduced solution space avoided the contradiction caused by the single target search method (window size). J.F. Grygierek and K. Grygierek [61] analyzed the life cycle cost optimization of single-family homes under changing climate conditions. Genetic algorithm was applied to explore many variables such as building orientation, types and sizes of windows, as well as the sum of window areas and was committed to building cooling and heating costs convergence. Y.N. Zhai et al. [62] tried a multiobjective optimization method to help designers choose the best window design solution. All the solutions provided in the pareto boundary diagram clearly demonstrated its performance. B. Lartigue et al. [63] introduced an evolutionary algorithm for optimizing the window-to-wall area ratio. The window parameters provide coordinated the holistic performance of multiple targets simultaneously. B.J. Futrell et al. [64] used a hybrid algorithm to optimize the daylighting and heat gain in the four directions of a classroom. Pareto efficient solutions helped decision makers with respect to tradeoffs between different orientations and design objectives. N. Delgarm et al. [65] applied a prototype model in the Middle East to verify the interaction between building parameters represented by window size and energy cost. The result of multistandard optimization was compared with those of single ones, and the effectiveness of the method was proven. S.Q. Gou et al. [66] employed the Monte Carlo method (MCA) to analyze the global sensitivity of input variables of apartment prototype in two climate zones in China. The artificial neural network (ANN) and nondominant sorting genetic algorithm (NSGA-II) were embedded in the passive strategy to control indoor temperature and expenditure during operation. T.M. Echenagucia et al. [67] investigated the number, location, and shape of windows in an open office building in multiple urban contexts. Refine search was performed for all cases. The analysis results demonstrated the delicate relationship between window layout and energy efficiency. A. Hani and T.A. Koiv [68] used a hybrid multidimensional optimization algorithm (GPSPSOCCHJ) in the optimization calculation of a modern office building. Quick selection maps of different elevation design schemes and annual total unit energy consumption were compiled. M. Khatami et al. [69] used the same technique in the optimization of glass curtain walls. M. Ferrara et al. [70] aimed at the optimization of individual classrooms. The selected particle swarm optimization algorithm (PSO) was configured with the geometric and material parameters involved and coordinated solutions ensured indoor environment and energy requirements. S. Carlucci and L. Pagliano [71,72] proposed a particle swarm optimization algorithm to improve the thermal comfort of net-zero energy buildings. The design strategy provided by the adaptive comfort model optimized the window area percentage and the glass unit. Subsequently, a new optimization study was conducted for indoor visual comfort. W. Yu et al. [73] described multiobjective optimization of a typical built environmental performance. The improved algorithm helped the multiple constraint variables of envelope design to be extensively weighed on several conflicting criteria.

The complexity and uncertainty of a large search space are inevitable problems in the integrated simulation and optimization of building energy consumption. The comparison and coordination of various algorithms is a universal solution [74]. K. Bamdada et al. [75] adopted a multiparameter combination strategy to solve the problems of typical commercial construction in four different climatic conditions in Australia. Compared with the three benchmark algorithms, the applied ant colony algorithm showed superiority. The selected aspect ratio of the window took into account the illumination 
level and energy efficiency. B.H. Si et al. [76] studied the influence of the shape of the compound slope roof on the building performance based on a new complex building. Mathematical description methods could not fully address the complexity presented by real-world building functions and forms. A high-precision surrogate model was developed and the effectiveness of four multiobjective algorithms was evaluated. A.T. Nguyen and S. Reiter [77] reported on the systematic global optimization design of low-cost housing in developing countries. Particle swarm optimization (PSO) and Hooke-Jeeves algorithm were combined to simulate and calculate a series of variables such as the square angle and window details. The results showed that there were many differences between naturally ventilated rooms and air-conditioned homes. P. IHM and M. Krati [78] optimized the envelope design of a single family villa in Tunisia. Combined with sequential search and violent search technology, the design features of residential buildings in specific locations were proposed. Compared with current residential design practices, annual energy cost was reduced by $50 \%$.

Envelope components are a major part of the building system. It is a vital element that verifies the indoor environmental quality, energy consumption, and architectural aesthetics [79]. Statistics have found that papers on building envelopes accounted for about $37 \%$ of all shares. The imaginative envelope design ensures the strong individual character of the building. Seventy percent of the work in the screened literature revolves around window configurations and building skin configurations (Table 1). Design variables include window form, location, window-to-wall ratio, aspect ratio, and curtain wall unit. The design of windows and curtain walls strongly depends on the architect's design awareness and the needs of the client. It can create a stylized architectural appearance and provide occupants with an attractive view. At the same time, their impact on the physical environment of the building has been widely recognized and given due attention. In contrast, some papers involve overhang thermophysical parameter descriptions. In order to avoid personal subjective judgment, it is classified as a holistic façade design study. One of the case studies on roof system is equally important [76]. 
Table 1. Literatures focused on design and optimization of building envelopes.

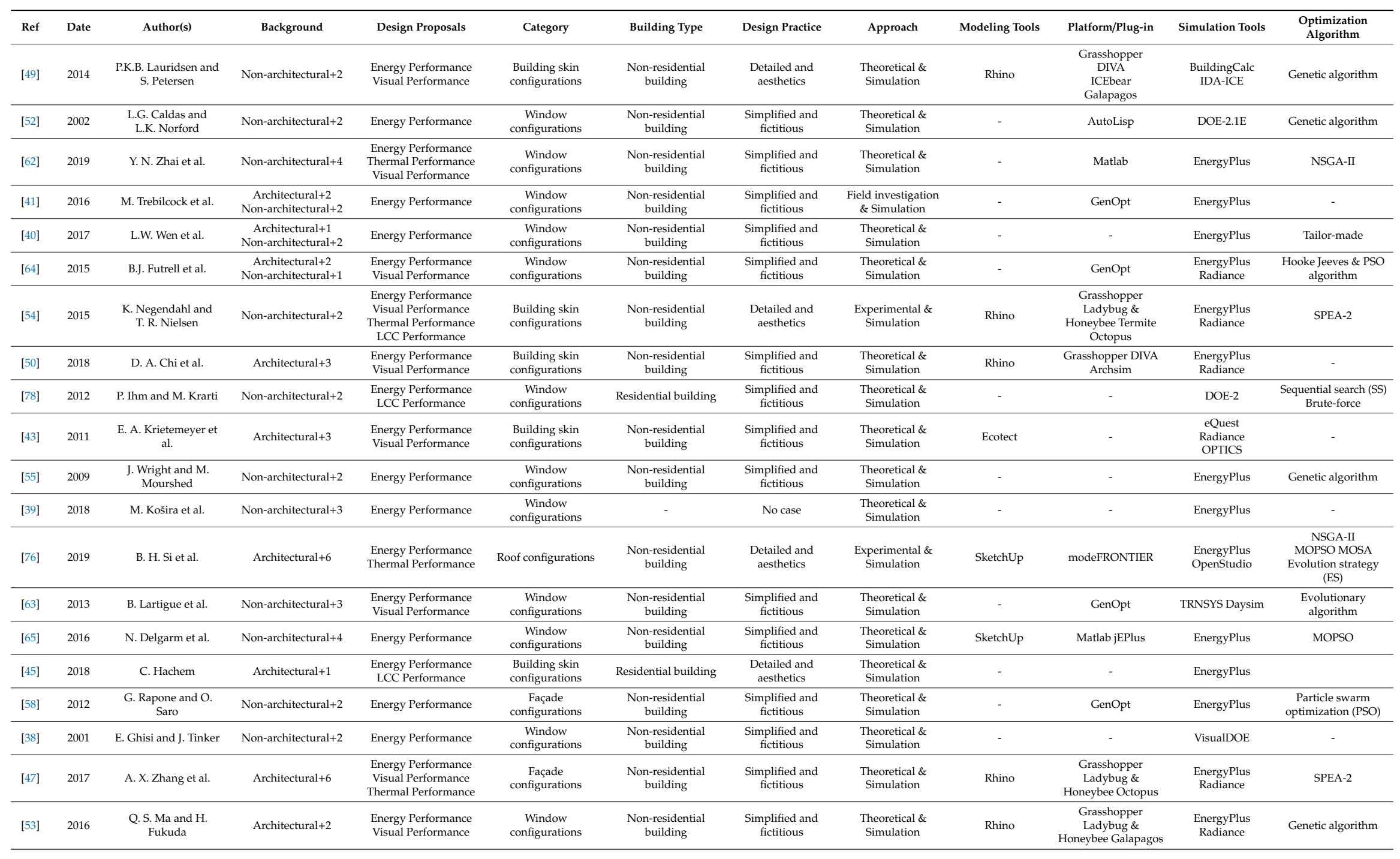


Table 1. Cont.

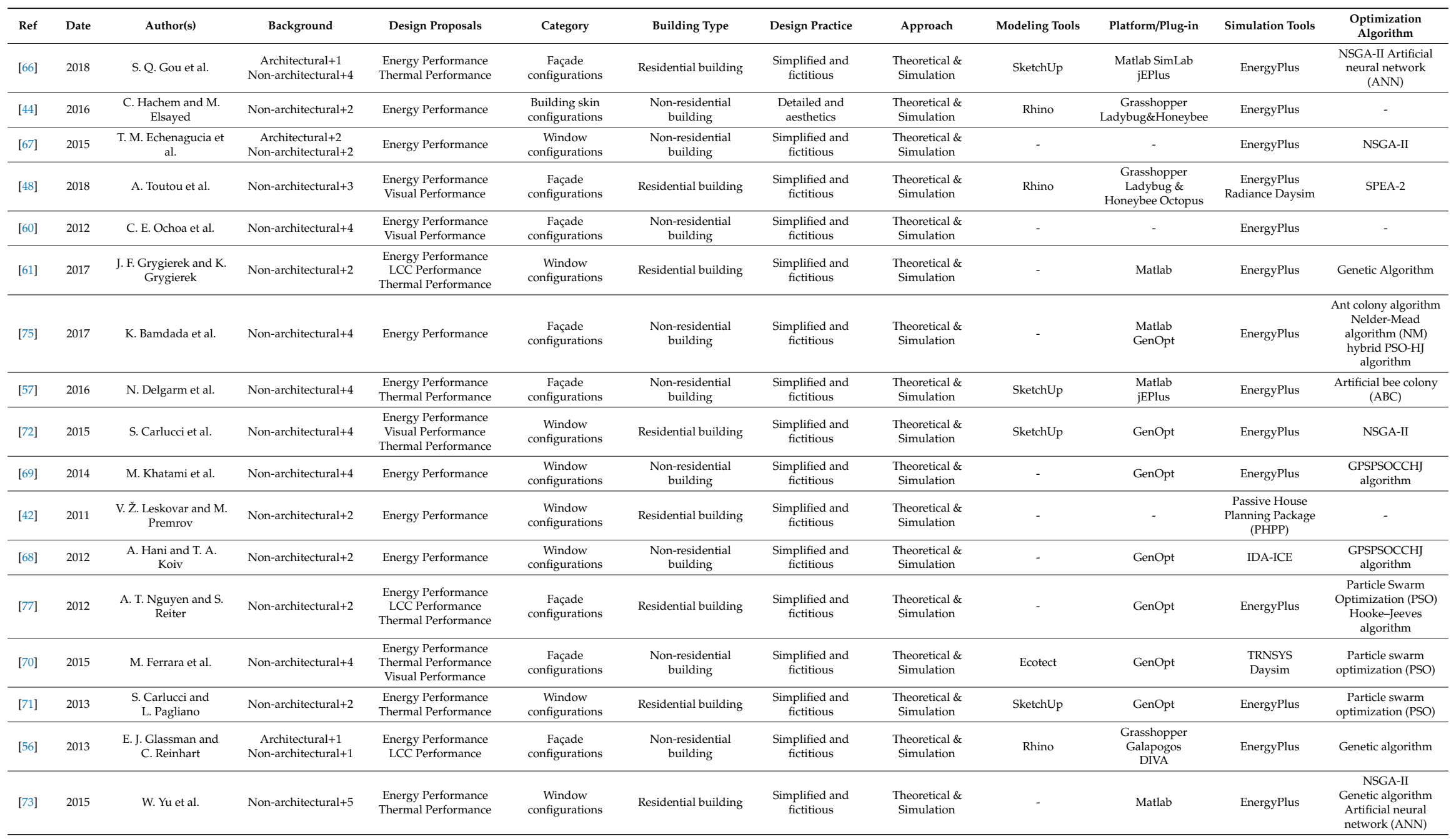




\subsection{Form}

Architectural form design is considered one of the most challenging tasks. Visualized and lifesome architecture always sparks discussion. In a sustainable context, building form is given more possibilities. A large number of strategies for optimizing and generating complex shapes have been found in the published data. The essence of finding a moderate architectural form is the process of solving a function because the solution set space can be nonlinear. M.S. Al-Homoud [80] mentioned a thermal optimization design method that combined energy simulation with direct search technology. It helped to quantify the shape characteristics of buildings under different climatic conditions (total building area, building height, and aspect ratio). W.S.S.W.M. Rashdi and M.R. Embi [81] found that the architectural form was a double-edged sword. Loose shape was not conducive to reducing solar radiation but had a higher cooling load. N.C. Brown and C.T. Mueller [82] discussed the research results of long-span building typology and based on finite element structure modeling and building energy consumption simulation, a variety of high-performance building form solutions were sought.

In areas with abundant natural resources, the connection between the architectural form and the microclimate environment has received increasing attention. Architects and users also appreciate integrated design (rather than support frames) to enhance the ornamental nature of the building. J. Shaeri et al. [83] conducted research on prototypes of multistory office buildings in three cities. The collision between the building extension and the dominant wind direction in the city was analyzed. With reference to statistics, the most suitable building shape under different climate conditions was determined. A.M.A. Youssef et al. [84] explored the feasibility of photovoltaic integration in large buildings. The design characteristics of multiple groups of building shapes were tested and evaluated in the study. The improved solution achieved the best photovoltaic utilization and reduced net energy consumption. C. Waibel et al. [85] implemented multiobjective optimization in a microclimate design workflow coupled with multiple simulations. In this study, the roof and facade of four office buildings were used as modeling variables and captured the essential dependencies between maximum renewable energy potential and minimum operating costs. I.G. Capeluto [86] introduced a concept design called solar energy collection envelope. The generated building shape made it possible to implement self-shading in a specific required time. Two completed works have carried out design studies on the energy efficiency of geometric attributes and layout plans and the direct relationship between natural energy use and candidate options has been systematically explored $[87,88]$.

The complexity of the optimization objective and the range of influence of the design variables determine the simulation run time. Sensitivity analysis is an effective preprocessing method that has been used to help identify decision variables and squeeze value ranges. T.L. Hemsath and K.A. Bandhosseini [89] explored the best way to filter the design properties of geometric parameters. Through the embedded sensitivity analysis, the statistical evaluation of the aspect ratio, the number of layers, and the shape were completed, and the important factors in the context of energy consumption were determined. The building shape was generated by genetic algorithm. D.T. Dubrow and M. Krarti [90] developed a procedure for selecting geometrical parameters of American benchmark residential buildings. For the simulation results of shape options, optimization tools arranged them in ascending order of fitness value. The results showed that the shape coefficients of two types of buildings always had energy saving potential under five different climatic conditions. S. Asadi et al. [91] demonstrated the selection and definition of independent variables affecting building energy consumption using Monte Carlo models. Multiple linear regression analysis was performed on design variables such as different contours, number of layers, and height. The calculation results were used in the optimization process to evaluate the energy cost of commercial buildings.

Multidisciplinary design teams often face complex data editing and transmission. In this case, the timeliness of the optimization method cannot be demonstrated, but also the potential risk of optimization failure is increased. The sophisticated multiobjective optimization framework can make more efficient design decisions according to the stated objectives and use simulation tools more purposefully in the optimization process. K.W. Chen et al. [92] constructed a design framework that 
integrated and optimized the shape of building and courtyard with cooling loads while ensuring daylight. The compromised design model took advantage of a statistical technique called prototype analysis to expand the possibilities of design. Z.W. Li et al. [93] realized energy efficiency optimization of representative building forms through a bidirectional workflow. Through rapid feedback indicators, the solution maintained the maximum proportion of functional areas and improved the natural lighting of the building without increasing energy costs. E. Lin and D. J. Gerber [94,95] initiated a design experiment on public buildings. The developed design model quickly collected quantitative and qualitative data and generated complex geometric shapes and analyzed their visualization effects, provided a building solution with better fitting performance. K. Konis et al. [96] developed a simulation-based passive architecture design framework based on the multi-engine parallel computing and visualization capabilities provided by the parametric tool platform. The form-finding component revealed the relationship between the building form combined with the floor plan and the inner courtyard and the energy use intensity.

On the basis of the powerful graphics processing and language programming ability of the computer, a variety of independently developed architectural shape design theories that expand or even surpass Euclidean geometry are another the important discoveries in this review. V. Granadeiro et al. [97] creatively developed a generative theory called "shape grammar". The computer coding design system established a direct connection between energy simulation and parametric design through complex grammatical transformations. The diversity of design was explored on the premise of ensuring the objective principle. L.G. Caldas $[98,99]$ conducted several design experiments on the work of the famous architect Alvaro Siza. The genetic algorithm was used as search engines to combine cost and energy evaluation criteria to generate shapes and execute design intent. Y.K. Yi and A.M. Malkawi [100] developed a novel approach to define form by controlling the hierarchical connection between building agent nodes. Syntax-based patterns overcame the limitations of common target control variables and integrated building performance optimization more smoothly into the design process. J.T. Jin and J.W. Jeong [101] proposed a design theory for free-form buildings. Parametric modeling tools were used to divide the surface of the building into finite elements. The heat gain and loss of buildings were estimated by genetic algorithm, so as to optimize energy consumption. A. Agirbas [102] conducted an energy efficiency analysis study on complex geometries. The design platform allowed forms to flow freely based on environmental interference factors. The generated conceptual design scheme had good performance in many indicators such as lighting, radiation, and building area. Furthermore, tailor-made computer design tools have been introduced in multiple studies. Interactive visualization platforms have helped architects explore different physical geometries and weighed the solution's energy, heat, and visual performance [103-105].

Twenty-six of the documents reviewed were involved in the optimization of the architectural form. With reference to all publications, among the mentioned design elements, scale factors (aspect ratio, surface volume ratio, etc.) of standard floor plans played an important role in the energy-saving optimization process related to building form (Table 2), covering almost all the ways in which physical design affects building energy consumption. Correspondingly, the shape and standard layer design information also belongs to the research dimension of architectural visual art. This novel design concept drives the dialogue between shape parameters and physical phenomena. Architectural forms can be regarded as a captured energy flow, which is expressed in the form of metaphors and analogies with the help of natural ecosystem mechanisms [106]. 
Table 2. Literatures focused on design and optimization of building form.

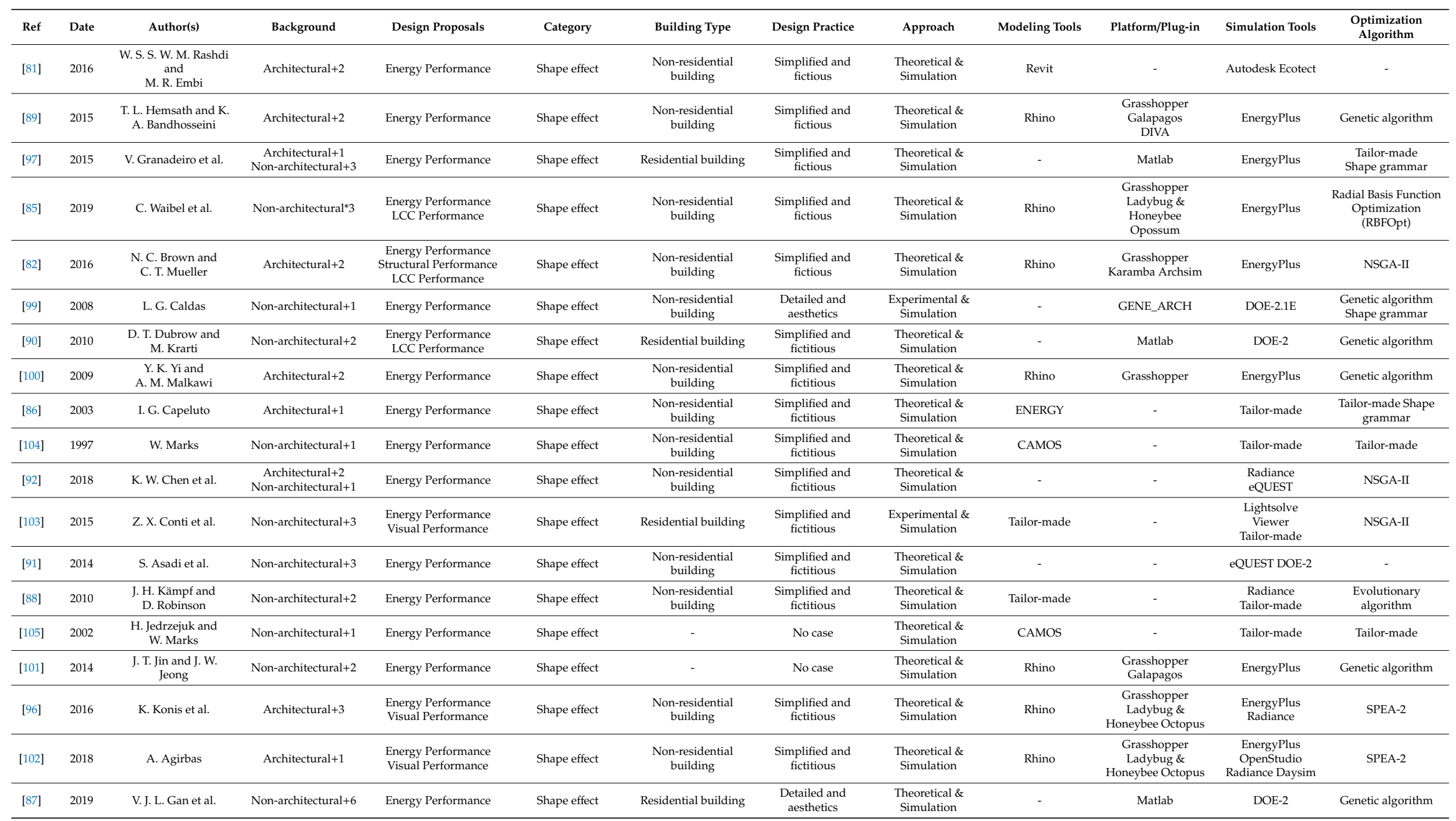


Table 2. Cont.

\begin{tabular}{|c|c|c|c|c|c|c|c|c|c|c|c|c|}
\hline Ref & Date & Author(s) & Background & Design Proposals & Category & Building Type & Design Practice & Approach & Modeling Tools & Platform/Plug-in & Simulation Tools & $\begin{array}{l}\text { Optimization } \\
\text { Algorithm }\end{array}$ \\
\hline [83] & 2019 & J. Shaeri et al. & $\begin{array}{c}\text { Architectural+2 } \\
\text { Non-architectural }+2 \\
\end{array}$ & Energy Performance & Shape effect & $\begin{array}{l}\text { Non-residential } \\
\text { building }\end{array}$ & $\begin{array}{c}\text { Simplified and } \\
\text { fictitious }\end{array}$ & $\begin{array}{l}\text { Theoretical \& } \\
\text { Simulation }\end{array}$ & - & - & $\begin{array}{c}\text { DesignBuilder } \\
\text { Radiance }\end{array}$ & - \\
\hline [98] & 2005 & L. G. Caldas & Non-architectural+1 & Energy Performance & Shape effect & $\begin{array}{c}\text { Non-residential } \\
\text { building }\end{array}$ & $\begin{array}{c}\text { Detailed and } \\
\text { aesthetics }\end{array}$ & $\begin{array}{c}\text { Theoretical \& } \\
\text { Simulation }\end{array}$ & - & - & DOE-2.1E & Genetic algorithm \\
\hline [93] & 2018 & Z. W. Li et al. & Architectural +4 & $\begin{array}{l}\text { Energy Performance } \\
\text { Visual Performance } \\
\end{array}$ & Shape effect & $\begin{array}{l}\text { Non-residential } \\
\text { building }\end{array}$ & $\begin{array}{l}\text { Simplified and } \\
\text { fictitious }\end{array}$ & $\begin{array}{c}\text { Theoretical \& } \\
\text { Simulation }\end{array}$ & - & Matlab & DesignBuilder & Genetic algorithm \\
\hline [84] & 2016 & A. M. A. Youssef et al. & Non-architectural +3 & $\begin{array}{l}\text { Energy Performance } \\
\text { LCC Performance }\end{array}$ & Shape effect & $\begin{array}{c}\text { Non-residential } \\
\text { building }\end{array}$ & $\begin{array}{l}\text { Simplified and } \\
\text { fictitious }\end{array}$ & $\begin{array}{l}\text { Theoretical \& } \\
\text { Simulation }\end{array}$ & - & GenOpt & DOE-2 & Genetic algorithm \\
\hline [80] & 2005 & M. S. Al-Homoud & Non-architectural +1 & Energy Performance & Shape effect & - & No case & $\begin{array}{c}\text { Theoretical \& } \\
\text { Simulation }\end{array}$ & - & $\begin{array}{c}\text { Matlab } \\
\text { modeFRONTIER }\end{array}$ & ENERCALC & Direct search \\
\hline [94] & 2014 & $\begin{array}{l}\text { S. H. E. Lin and D. J. } \\
\text { Gerber }\end{array}$ & Architectural+2 & $\begin{array}{l}\text { Energy Performance } \\
\text { LCC Performance }\end{array}$ & Shape effect & $\begin{array}{c}\text { Non-residential } \\
\text { building }\end{array}$ & $\begin{array}{c}\text { Detailed and } \\
\text { aesthetics }\end{array}$ & $\begin{array}{c}\text { Theoretical \& } \\
\text { Simulation }\end{array}$ & Revit & $\begin{array}{l}\text { Microsoft Excel } \\
\text { Mattlab }\end{array}$ & $\begin{array}{c}\text { Green Building } \\
\text { Studio }\end{array}$ & Genetic algorithm \\
\hline [95] & 2014 & $\begin{array}{l}\text { D. J. Gerber and S. H. } \\
\text { E. Lin }\end{array}$ & Architectural +2 & $\begin{array}{l}\text { Energy Performance } \\
\text { LCC Performance }\end{array}$ & Shape effect & $\begin{array}{l}\text { Non-residential } \\
\text { building }\end{array}$ & $\begin{array}{c}\text { Detailed and } \\
\text { aesthetics }\end{array}$ & $\begin{array}{l}\text { Theoretical \& } \\
\text { Simulation }\end{array}$ & Revit & $\begin{array}{l}\text { Microsoft Excel } \\
\text { Matlab }\end{array}$ & $\begin{array}{l}\text { Green Building } \\
\text { Studio }\end{array}$ & Genetic algorithm \\
\hline
\end{tabular}




\subsection{Shading Systems}

As part of the building envelope, the shading systems is designed to avoid unwanted daylight from causing undesired indoor temperature and lighting environment and reduce the additional operating costs of the building system. In order to meet a user's preferences, the shading system enhances the building's identity and reflects personal design capabilities. Therefore, this review lists them separately. Most of the commonly used shading devices are regarded as a passive measure. The basic principle is that no additional electrical equipment is required. L. Bellia et al. [107] analyzed the influence of the geometric characteristics of outdoor shading on the energy cost of typical office buildings in Italy. Simplified design standards were provided for engineers and architects. J.T. Kim and G. Kim [108] designed a combined external shading device and produced a miniature scale model. Experiments and simulations proved that it could effectively minimize the adverse effect of direct sunlight on the cooling load and improved the uniformity of illumination. H.H. Alzoubi and A.H. AlZoubi [109] performed a simulation comparison of three different shading designs. The illumination and energy consumption of the device were evaluated through field investigation. F. Mazzichi and M. Manzan [110] showed the interference of different types of shading on heating, cooling, and lighting equipment during office building occupation. The analysis indicated that the mixed device composed of fixed overhangs and shutters had an obvious effect. A.K. Furundžić et al. [111] simulated different exterior shading conceptual models of a typical office building. A comparative analysis of multiple scenarios showed that shading facilities not only affect building energy efficiency, but also participate in carbon emissions. A. Sherif et al. [112,113], inspired by elements of vernacular architecture, invented a wooden perforated shading system. By controlling the rotation angle of the solar screen, the desired energy saving goal was achieved and the glare was significantly reduced. M.C. Ho et al. [114] conducted field tests on the indoor illuminance of a typical classroom under various conditions. After verifying the effectiveness of the simulation scheme, a number of different combinations of shading designs were considered for candidates that demonstrated promising energy performance. A.K.K. Lau et al. [115] carried out targeted research on the shading system of high-rise buildings with large glass curtain walls. The simulation data of 20 sets of different facade orientations and different types of devices were compared. The results of the analysis showed that the application of shading devices was urgently needed on the east and west facades. It also clarified that the shading device had more energy-saving prospects than high-performance glass. F. Yassine and B.A. Hijleh [116] examined the energy-saving potential of horizontal overhangs, vertical fins, horizontal louvers, and vertical louvers and found that the parameters of rotation angle and protrusion length were more important than the orientation of the facade. A. Ghosh and S. Neogi [117] summarized the interference of building geometric elements on energy consumption, and tailored an external shading system. The applicability of the new equipment was verified through three different climatic data. F.F. Hernández et al. [118] evaluated the use of shading devices for high-light transmission office buildings in Mediterranean cities. Studies have shown that shading devices are an effective solution to the energy consumption and visual comfort of local buildings. But the type of glass and the weather parameters cannot be ignored. S. Liu et al. [119] suggested using shading devices on the opaque facades of public rental housing in Hong Kong. Different configurations such as the length, number, and tilt angle of the light shielding plate were discussed, and the maximum interference with energy efficiency was achieved. M. Alshayeb et al. [120] drafted three energy-saving measures for an upcoming medical center. Calculations showed that a 1:1 window shadow ratio dramatically reduced the cooling load.

Considering the interaction of all variables in a decision and scanning the predefined range of each parameter line-by-line is a daunting task. A multi-benchmark parallel operation based on a parameterized information platform has been a recommended method. C. Kasinalis et al. [121] studied the correlation between the surface area of dynamic shading and the window-to-wall ratio in terms of energy saving potential. D.R. Ossen et al. [122] performed a parametric study on various performance variables of external overhang. The relationship between cooling load and daylight level, as well as the geometry of the horizontal shading, were analyzed. A. Wagdy and F. Fathy [123] 
introduced an exhaustive search method for shading systems. Convergent solutions selected with a combination of multiple design variables such as window-to-wall ratio, number of shutters, and shutter angle reflected the general trend of building performance. M.V. Nielsen et al. [124] investigated various types of shading using cooling, heating, and lighting as metrics. The results showed that dynamic shading performed the best in total energy consumption and sunlight environment tests and the optimal solution revealed a high degree of dependence between design variables. A. Eltaweel and Y. Su $[125,126]$ designed an automated venetian blinds for office buildings and controlled the length, width, interval, and specific rotation angle of each slat based on parameterized means. Specific dates (spring breeze, summer solstice, and east solstice) were selected to verify the conditions of the shading element. It was proven that the system was superior to traditional shutters considering energy reducing and indoor comfort. J. González and F. Fiorito [127] solved the external shadow optimization of typical office space with the same strategy. The energy efficiency and emissions of alternatives were recognized as better than industry standards.

In the meantime, in order to effectively access complex targets, it has been found that a large number of studies have coupled evolutionary algorithms with building energy optimization programs. To date, this has be called a mainstream technology trend. H. Sghiouri et al. [128] studied the control parameters of fixed shading of external windows in three climate cities. Through the use of genetic algorithms, the performance optimization of different regions and orientations was completed. Evidence showed that there was no contradiction between improving environmental quality and regulating energy saving. M. Manzan and F. Pinto $[129,130]$ studied the energy consumption of external shading in different climatic conditions. The coupled multiobjective algorithm referenced configuration variables such as rotation angle, overhang length, and glass system and a correlation scheme was generated. A. Kirimtat et al. [131] designed a novel amorphous shading apparatus and constrained the design solution with two mutually interfering goals (total energy consumption and effective daylight). The applicability of the two algorithms was compared based on performance evaluation criteria. $\mathrm{M}$. Khoroshiltseva et al. [132] designed fixed shading instruments for the exterior walls of residential buildings. A Harmony Search-based design derivation method was used to reduce the operation cost while maintaining the lighting comfort. The effectiveness of the shading was characterized by the analysis data. Additionally, according to observations, the user-friendly and customized collaborative optimization module solved conflicting design goals in a reasonable running time [133,134].

With the introduction of kinetic motion, contemporary architecture has developed to a stage of self-adaptation and response. Building have the ability to physically reconfigure themselves to accommodate the variability of location or geometry [135]. E.T. Cachat et al. [136] proposed a photovoltaic integrated dynamic shading device (PVDS) design scheme. The facility overcame the limitations of standard shading systems and showed advantages by improving illumination and energy consumption. It also emphasized that the optimization plan could not meet three goals at the same time, and special tradeoffs were needed. M.M.S. Ahmed et al. [137] reported the experimental results of an intelligent dynamic shading system applied to residential buildings. The system consisted of a vertical movable frame and a horizontal turnover plate, which were fixed on a window facing south. Room temperature and energy consumption were recorded separately. The measured data indicated that the device could effectively reduce cooling energy consumption. S. Adriaenssens et al. [138] designed a shape-shifting modular shading system based on dialectic form finding. The purpose of restraining solar radiation was achieved by adjusting the degree of bending and complex motion of the controlled flexible shell. Experiments exhibited that the shading module could effectively reduce the annual load. L. Giovannini et al. [139] developed an adaptive shape variable shading system for arid climates. By controlling the opening and closing mechanism and the porosity of the polygon module, the purpose of energy saving was achieved. Analysis shown that the device was more efficient than external shutters and reflective glass. M. Manzana and R. Padovana [140] designed a hybrid shading system based on changes in the solar position in summer and winter. Fixed shading and real-time activated blinds provided a new solution for energy savings. In subsequent studies, the control 
system was optimized in more detail based on the occupancy schedule, thereby minimizing shutter activation [141]. M. Pesenti et al. [142] invented a microactuator adaptive shading device. The opacity of the origami shading system was controlled by overlapping folds and angle changes. The contribution of the equipment to reducing energy consumption and indoor daylight distribution was highlighted. Z. Nagy et al. [143] introduced a dynamic self-shading system constructed from a lightweight frame and a rectangular photovoltaic module. PV panels driven by pneumatic actuators resisted unwanted light while tracking the sun's position. The simulation results showed the superiority of energy saving and solar power generation.

All the reviewed texts (36 copies) pointed out that the classification of shading systems is closely related to the types of natural resources, climate attributes, solar azimuth, and other environmental factors involved [144]. Similar to the other elements in the building, a cantilever exposed to the microclimate, shutters, and various prefabricated adjustable modules form the design language of the shading system (Table 3). A fixed shading device shows the advantages of easy installation and cost controllability. Therefore, the application research in this field is widely distributed in this survey, accounting for $68 \%$ of the total. However, its cross-seasonal energy performance has limitations [145]. With the rapid development of adaptive building theory and mechanical dynamics knowledge, movable shading devices are gradually popularized. Accordingly, complex construction and excessive installation and maintenance costs has become obstacles to further promotion. The adaptability and sustainability demonstrated by the hybrid system provide designers with more choices, which is a promising research direction. 
Table 3. Literatures focused on design and optimization of shading system.

\begin{tabular}{|c|c|c|c|c|c|c|c|c|c|c|c|c|}
\hline Ref & Date & Author(s) & Background & Design Proposals & Category & Building Type & Design Practice & Approach & Modeling Tools & Platform/Plug-in & Simulation Tools & $\begin{array}{c}\text { Optimization } \\
\text { Algorithm }\end{array}$ \\
\hline [132] & 2016 & $\begin{array}{l}\text { M. Khoroshiltseva et } \\
\text { al. }\end{array}$ & Non-architectural+3 & $\begin{array}{l}\text { Energy Performance } \\
\text { Thermal Performance }\end{array}$ & Fixed Shading & Residential building & $\begin{array}{l}\text { Simplified and } \\
\text { fictitious }\end{array}$ & $\begin{array}{c}\text { Theoretical \& } \\
\text { Simulation }\end{array}$ & SketchUp & - & EnergyPlus & $\begin{array}{l}\text { Harmony Search } \\
\text { Algorithms }\end{array}$ \\
\hline [108] & 2010 & J. T. Kim and G. Kim & Architectural+2 & $\begin{array}{l}\text { Energy Performance } \\
\text { Visual Performance }\end{array}$ & Fixed Shading & Residential building & $\begin{array}{c}\text { Detailed and } \\
\text { aesthetics }\end{array}$ & $\begin{array}{c}\text { Experimental \& } \\
\text { Simulation }\end{array}$ & $\begin{array}{c}\text { Revit } \\
\text { Architecture } \\
\text { Revit MEP }\end{array}$ & - & IES-VE Radiance & - \\
\hline [109] & 2010 & $\begin{array}{l}\text { H. H. Alzoubi and A. } \\
\text { H. AlZoubi }\end{array}$ & Architectural +2 & $\begin{array}{l}\text { Energy Performance } \\
\text { Visual Performance }\end{array}$ & Fixed Shading & $\begin{array}{c}\text { Non-residential } \\
\text { building }\end{array}$ & $\begin{array}{l}\text { Simplified and } \\
\text { fictitious }\end{array}$ & $\begin{array}{l}\text { Field investigation } \\
\text { \& Simulation }\end{array}$ & - & - & Lightscape & - \\
\hline [110] & 2013 & $\begin{array}{l}\text { F. Mazzichi and } \\
\text { M. Manzan }\end{array}$ & Non-architectural+2 & $\begin{array}{l}\text { Energy Performance } \\
\text { Visual Performance }\end{array}$ & Hybrid shading & $\begin{array}{c}\text { Non-residential } \\
\text { building }\end{array}$ & $\begin{array}{l}\text { Simplified and } \\
\text { fictitious }\end{array}$ & $\begin{array}{l}\text { Theoretical \& } \\
\text { Simulation }\end{array}$ & - & - & ESP-r Daysim & - \\
\hline [111] & 2019 & A. K. Furundžić et al. & Architectural +2 & $\begin{array}{l}\text { Energy Performance } \\
\text { LCC Performance }\end{array}$ & Fixed Shading & $\begin{array}{c}\text { Non-residential } \\
\text { building }\end{array}$ & $\begin{array}{c}\text { Simplified and } \\
\text { fictitious }\end{array}$ & $\begin{array}{c}\begin{array}{c}\text { Theoretical \& } \\
\text { Simulation }\end{array} \\
\end{array}$ & SketchUp & OpenStudio & EnergyPlus & - \\
\hline [113] & 2013 & A. Sherif et al. & $\begin{array}{c}\text { Architectural+1 } \\
\text { Non-architectural }+2 \\
\end{array}$ & Energy Performance & Fixed Shading & Residential building & $\begin{array}{c}\text { Simplified and } \\
\text { fictitious }\end{array}$ & $\begin{array}{c}\begin{array}{c}\text { Theoretical \& } \\
\text { Simulation }\end{array} \\
\end{array}$ & DesignBuilder & - & EnergyPlus & - \\
\hline [112] & 2012 & A. Sherif et al. & $\begin{array}{c}\text { Architectural+1 } \\
\text { Non-architectural+2 }\end{array}$ & Energy Performance & Fixed Shading & Residential building & $\begin{array}{c}\text { Simplified and } \\
\text { fictitious }\end{array}$ & $\begin{array}{c}\text { Theoretical \& } \\
\text { Simulation }\end{array}$ & DesignBuilder & - & EnergyPlus & - \\
\hline [130] & 2014 & M. Manzan & Non-architectural+1 & $\begin{array}{l}\text { Energy Performance } \\
\text { Visual Performance }\end{array}$ & Fixed Shading & $\begin{array}{c}\text { Non-residential } \\
\text { building }\end{array}$ & $\begin{array}{c}\text { Simplified and } \\
\text { fictitious }\end{array}$ & $\begin{array}{c}\text { Theoretical \& } \\
\text { Simulation }\end{array}$ & - & modeFRONTIER & ESP-r Daysim & NSGA-II \\
\hline [129] & 2009 & $\begin{array}{l}\text { M. Manzan and } \\
\text { F. Pinto }\end{array}$ & Non-architectural+2 & Energy Performance & Fixed Shading & $\begin{array}{l}\text { Non-residential } \\
\text { building }\end{array}$ & $\begin{array}{l}\text { Simplified and } \\
\text { fictitious }\end{array}$ & $\begin{array}{l}\text { Theoretical \& } \\
\text { Simulation }\end{array}$ & - & modeFRONTIER & ESP-r Radiance & $\begin{array}{l}\text { Multio-bjective } \\
\text { Genetic Optimization } \\
\text { (MOGA-II) }\end{array}$ \\
\hline [122] & 2005 & D. R. Ossen et al. & Architectural +3 & Energy Performance & Fixed Shading & $\begin{array}{l}\text { Non-residential } \\
\text { building }\end{array}$ & $\begin{array}{l}\text { Simplified and } \\
\text { fictitious }\end{array}$ & $\begin{array}{l}\text { Theoretical \& } \\
\text { Simulation }\end{array}$ & - & - & eQUEST & 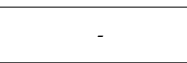 \\
\hline [131] & 2019 & A. Kirimtat et al. & $\begin{array}{c}\text { Architectural+1 } \\
\text { Non-architectural+3 }\end{array}$ & $\begin{array}{l}\text { Energy Performance } \\
\text { Visual Performance }\end{array}$ & Fixed Shading & $\begin{array}{c}\text { Non-residential } \\
\text { building }\end{array}$ & $\begin{array}{l}\text { Simplified and } \\
\text { fictitious }\end{array}$ & $\begin{array}{l}\text { Theoretical \& } \\
\text { Simulation }\end{array}$ & - & - & $\begin{array}{l}\text { EnergyPlus } \\
\text { Radiance }\end{array}$ & $\begin{array}{c}\text { NSGA-II } \\
\text { Self-adaptive } \\
\text { continuous genetic } \\
\text { algorithm } \\
\text { with differential } \\
\text { evolution (cGA-DE) }\end{array}$ \\
\hline [128] & 2018 & H. Sghiouri et al. & Non-architectural+4 & $\begin{array}{l}\text { Energy Performance } \\
\text { Thermal Performance }\end{array}$ & Fixed Shading & Residential building & $\begin{array}{l}\text { Simplified and } \\
\text { fictitious }\end{array}$ & $\begin{array}{l}\text { Theoretical \& } \\
\text { Simulation }\end{array}$ & SketchUp & $\begin{array}{l}\begin{array}{c}\text { jEPlus+EA } \\
\text { TRNSYS3D }\end{array} \\
\text { ThS }\end{array}$ & TRNSYS & NSGA-II \\
\hline [141] & 2017 & $\begin{array}{l}\text { M. Manzan and } \\
\text { A. Clarich }\end{array}$ & Non-architectural+2 & Energy Performance & Fixed Shading & $\begin{array}{c}\text { Non-residential } \\
\text { building }\end{array}$ & $\begin{array}{c}\text { Simplified and } \\
\text { fictitious }\end{array}$ & $\begin{array}{c}\text { Theoretical \& } \\
\text { Simulation }\end{array}$ & - & modeFRONTIER & ESP-r Daysim & FAST algorithm \\
\hline [114] & 2008 & M. C. Ho et al. & $\begin{array}{c}\text { Architectural+3 } \\
\text { Non-architectural }+2\end{array}$ & $\begin{array}{l}\text { Energy Performance } \\
\text { Visual Performance }\end{array}$ & Fixed Shading & $\begin{array}{c}\text { Non-residential } \\
\text { building }\end{array}$ & $\begin{array}{c}\text { Simplified and } \\
\text { fictitious }\end{array}$ & $\begin{array}{l}\text { Field investigation } \\
\text { \& Simulation }\end{array}$ & - & - & $\begin{array}{c}\text { IES-CPC } \\
\text { Lightscape }\end{array}$ & - \\
\hline [115] & 2016 & A. K. K. Lau et al. & Non-architectural+4 & Energy Performance & Fixed Shading & $\begin{array}{c}\text { Non-residential } \\
\text { building }\end{array}$ & $\begin{array}{c}\text { Simplified and } \\
\text { fictitious }\end{array}$ & $\begin{array}{l}\text { Theoretical \& } \\
\text { Simulation }\end{array}$ & - & - & IES-VE & - \\
\hline [116] & 2013 & $\begin{array}{l}\text { F. Yassine and } \\
\text { B. A. Hijleh }\end{array}$ & Non-architectural +4 & Energy Performance & Fixed Shading & $\begin{array}{l}\text { Non-residential } \\
\text { building }\end{array}$ & $\begin{array}{l}\text { Simplified and } \\
\text { fictitious }\end{array}$ & $\begin{array}{l}\text { Theoretical \& } \\
\text { Simulation }\end{array}$ & - & - & IES-VE & - \\
\hline [117] & 2018 & $\begin{array}{l}\text { A. Ghosh and S. } \\
\text { Neogi }\end{array}$ & Non-architectural+2 & Energy Performance & Fixed Shading & $\begin{array}{c}\text { Non-residential } \\
\text { building }\end{array}$ & $\begin{array}{c}\text { Simplified and } \\
\text { fictitious }\end{array}$ & $\begin{array}{c}\text { Theoretical \& } \\
\text { Simulation }\end{array}$ & SketchUp & - & EnergyPlus & - \\
\hline [118] & 2017 & F. F. Hernández et al. & Non-architectural+5 & $\begin{array}{l}\text { Energy Performance } \\
\text { Visual Performance }\end{array}$ & Fixed Shading & $\begin{array}{l}\text { Non-residential } \\
\text { building }\end{array}$ & $\begin{array}{l}\text { Simplified and } \\
\text { fictitious }\end{array}$ & $\begin{array}{l}\text { Theoretical \& } \\
\text { Simulation }\end{array}$ & SketchUp & OpenStudio & $\begin{array}{c}\text { EnergyPlus } \\
\text { TRNSYS } \\
\text { Evalglare Daysim } \\
\text { Radiance }\end{array}$ & - \\
\hline
\end{tabular}


Table 3. Cont

\begin{tabular}{|c|c|c|c|c|c|c|c|c|c|c|c|c|}
\hline Ref & Date & Author(s) & Background & Design Proposals & Category & Building Type & Design Practice & Approach & Modeling Tools & Platform/Plug-in & Simulation Tools & $\begin{array}{c}\text { Optimization } \\
\text { Algorithm }\end{array}$ \\
\hline [136] & 2019 & E. T. Cachat et al. & Architectural +4 & $\begin{array}{l}\text { Energy Performance } \\
\text { Visual Performance } \\
\text { LCC Performance }\end{array}$ & Fixed Shading & $\begin{array}{l}\text { Non-residential } \\
\text { building }\end{array}$ & $\begin{array}{l}\text { Simplified and } \\
\text { fictitious }\end{array}$ & $\begin{array}{l}\text { Theoretical \& } \\
\text { Simulation }\end{array}$ & Rhino & $\begin{array}{c}\text { Grasshopper } \\
\text { Ladybug \& } \\
\text { Honeybee Octopus }\end{array}$ & $\begin{array}{l}\text { EnergyPlus } \\
\text { Radiance }\end{array}$ & Genetic algorithm \\
\hline [119] & 2019 & S. Liu et al. & $\begin{array}{c}\text { Architectural }+3 \\
\text { Non-architectural }+2\end{array}$ & Energy Performance & Fixed Shading & Residential building & $\begin{array}{l}\text { Simplified and } \\
\text { fictitious }\end{array}$ & $\begin{array}{l}\text { Theoretical \& } \\
\text { Simulation }\end{array}$ & - & - & EnergyPlus & - \\
\hline [120] & 2015 & M. Alshayeb et al. & Architectural+3 & Energy Performance & Fixed Shading & $\begin{array}{l}\text { Non-residential } \\
\text { building }\end{array}$ & $\begin{array}{l}\text { Simplified and } \\
\text { fictitious }\end{array}$ & $\begin{array}{c}\text { Theoretical \& } \\
\text { Simulation }\end{array}$ & - & - & EnergyPlus & - \\
\hline [107] & 2013 & L. Bellia et al. & Non-architectural +3 & Energy Performance & Fixed Shading & $\begin{array}{c}\text { Non-residential } \\
\text { building }\end{array}$ & $\begin{array}{c}\text { Simplified and } \\
\text { fictitious }\end{array}$ & $\begin{array}{c}\text { Theoretical \& } \\
\text { Simulation }\end{array}$ & - & - & EnergyPlus & - \\
\hline [137] & 2016 & M. M. S. Ahmed et al. & Non-architectural +4 & Energy Performance & Dynamic Shading & Residential building & $\begin{array}{c}\text { Detailed and } \\
\text { aesthetics }\end{array}$ & $\begin{array}{l}\text { Field investigation } \\
\text { \& Simulation }\end{array}$ & Rhino & Grasshopper & $\begin{array}{c}\text { Meteotest } \\
\text { Tailor-made }\end{array}$ & - \\
\hline [125] & 2017 & A. Eltaweel and Y. Su & Architectural+2 & $\begin{array}{l}\text { Energy Performance } \\
\text { Visual Performance }\end{array}$ & Dynamic Shading & $\begin{array}{l}\text { Non-residential } \\
\text { building }\end{array}$ & $\begin{array}{c}\text { Simplified and } \\
\text { fictitious }\end{array}$ & $\begin{array}{l}\text { Theoretical \& } \\
\text { Simulation }\end{array}$ & Rhino & $\begin{array}{c}\text { Grasshopper } \\
\text { Ladybug \& } \\
\text { Honeybee }\end{array}$ & $\begin{array}{c}\text { EnergyPlus } \\
\text { Daysim Radiance }\end{array}$ & - \\
\hline [127] & 2015 & $\begin{array}{l}\text { J. González and } \\
\text { F. Fiorito }\end{array}$ & Architectural+2 & $\begin{array}{l}\text { Energy Performance } \\
\text { Visual Performance } \\
\text { LCC Performance }\end{array}$ & Dynamic Shading & $\begin{array}{l}\text { Non-residential } \\
\text { building }\end{array}$ & $\begin{array}{l}\text { Simplified and } \\
\text { fictitious }\end{array}$ & $\begin{array}{l}\text { Theoretical \& } \\
\text { Simulation }\end{array}$ & Rhino & $\begin{array}{c}\text { Grasshopper } \\
\text { Galapagos DIVA }\end{array}$ & $\begin{array}{c}\text { EnergyPlus } \\
\text { Daysim Radiance }\end{array}$ & Genetic algorithm \\
\hline [138] & 2014 & S. Adriaenssens et al. & $\begin{array}{c}\text { Architectural+1 } \\
\text { Non-architectural+6 }\end{array}$ & Energy Performance & Dynamic Shading & $\begin{array}{c}\text { Non-residential } \\
\text { building }\end{array}$ & $\begin{array}{c}\text { Simplified and } \\
\text { fictitious }\end{array}$ & $\begin{array}{c}\text { Theoretical \& } \\
\text { Simulation }\end{array}$ & Ecotect & - & EnergyPlus & - \\
\hline [139] & 2015 & L. Giovannini et al. & Non-architectural +4 & $\begin{array}{l}\text { Energy Performance } \\
\text { Visual Performance }\end{array}$ & Dynamic Shading & $\begin{array}{c}\text { Non-residential } \\
\text { building }\end{array}$ & $\begin{array}{c}\text { Detailed and } \\
\text { aesthetics }\end{array}$ & $\begin{array}{c}\text { Theoretical \& } \\
\text { Simulation }\end{array}$ & Rhino & Grasshopper DIVA & IES-VE Daysim & - \\
\hline [140] & 2015 & $\begin{array}{l}\text { M. Manzana and R. } \\
\text { Padovana }\end{array}$ & Non-architectural +2 & $\begin{array}{l}\text { Energy Performance } \\
\text { Visual Performance }\end{array}$ & Hybrid shading & $\begin{array}{l}\text { Non-residential } \\
\text { building }\end{array}$ & $\begin{array}{l}\text { Simplified and } \\
\text { fictitious }\end{array}$ & $\begin{array}{l}\text { Theoretical \& } \\
\text { Simulation }\end{array}$ & & modeFRONTIER & ESP-r Daysim & FAST algorithm \\
\hline [124] & 2011 & M. V. Nielsen et al. & Non-architectural+3 & $\begin{array}{l}\text { Energy Performance } \\
\text { Visual Performance }\end{array}$ & Hybrid shading & $\begin{array}{c}\text { Non-residential } \\
\text { building }\end{array}$ & $\begin{array}{c}\text { Simplified and } \\
\text { fictitious }\end{array}$ & $\begin{array}{c}\begin{array}{c}\text { Theoretical \& } \\
\text { Simulation }\end{array} \\
\end{array}$ & - & Matlab & $\begin{array}{l}\text { BuildingCalc } \\
\text { LightCalc }\end{array}$ & - \\
\hline [143] & 2016 & Z. Nagy et al. & Architectural +8 & $\begin{array}{l}\text { Energy Performance } \\
\text { LCC Performance }\end{array}$ & Dynamic Shading & $\begin{array}{l}\text { Non-residential } \\
\text { building }\end{array}$ & $\begin{array}{c}\text { Detailed and } \\
\text { aesthetics }\end{array}$ & $\begin{array}{l}\text { Field investigation } \\
\text { \& Simulation }\end{array}$ & Rhino & Matlab Grasshopper & EnergyPlus & \\
\hline [126] & 2017 & $\begin{array}{l}\text { A. Eltaweel and } \\
\text { Y. Su }\end{array}$ & Architectural+2 & $\begin{array}{l}\text { Energy Performance } \\
\text { Visual Performance }\end{array}$ & Dynamic Shading & $\begin{array}{l}\text { Non-residential } \\
\text { building }\end{array}$ & $\begin{array}{l}\text { Simplified and } \\
\text { fictitious }\end{array}$ & $\begin{array}{l}\text { Theoretical \& } \\
\text { Simulation }\end{array}$ & Rhino & $\begin{array}{c}\text { Grasshopper } \\
\text { Ladybug \& } \\
\text { Honeybee }\end{array}$ & $\begin{array}{c}\text { EnergyPlus } \\
\text { Daysim Radiance }\end{array}$ & - \\
\hline [121] & 2014 & C. Kasinalis et al. & Non-architectural+4 & $\begin{array}{l}\text { Energy Performance } \\
\text { Visual Performance } \\
\text { Thermal Performance }\end{array}$ & Dynamic Shading & $\begin{array}{l}\text { Non-residential } \\
\text { building }\end{array}$ & $\begin{array}{l}\text { Simplified and } \\
\text { fictitious }\end{array}$ & $\begin{array}{l}\text { Theoretical \& } \\
\text { Simulation }\end{array}$ & - & - & TRNSYS Daysim & NSGA-II \\
\hline [133] & 2014 & R. Shan & Architectural +1 & Energy Performance & Fixed Shading & $\begin{array}{c}\text { Non-residential } \\
\text { building }\end{array}$ & $\begin{array}{c}\text { Simplified and } \\
\text { fictitious }\end{array}$ & $\begin{array}{l}\text { Theoretical \& } \\
\text { Simulation }\end{array}$ & & & TRNSYS Daysim & Genetic algorithm \\
\hline [134] & 2016 & $\begin{array}{l}\text { M. Mahdavinejad } \\
\text { and } \\
\text { S. Mohammadi }\end{array}$ & Architectural +2 & $\begin{array}{l}\text { Energy Performance } \\
\text { Visual Performance }\end{array}$ & Fixed Shading & $\begin{array}{l}\text { Non-residential } \\
\text { building }\end{array}$ & $\begin{array}{l}\text { Simplified and } \\
\text { fictitious }\end{array}$ & $\begin{array}{l}\text { Theoretical \& } \\
\text { Simulation }\end{array}$ & Rhino & $\begin{array}{l}\text { Grasshopper DIVA } \\
\text { Octopus }\end{array}$ & $\begin{array}{c}\text { EnergyPlus } \\
\text { Radiance Daysim }\end{array}$ & SPEA-2 \\
\hline [123] & 2015 & $\begin{array}{l}\text { A. Wagdy and } \\
\text { F. Fathy }\end{array}$ & $\begin{array}{c}\text { Architectural+1 }+1 \\
\text { Non-architecturall+1 }\end{array}$ & $\begin{array}{l}\text { Energy Performance } \\
\text { Visual Performance }\end{array}$ & Fixed Shading & $\begin{array}{l}\text { Non-residential } \\
\text { building }\end{array}$ & $\begin{array}{l}\text { Simplified and } \\
\text { fictitious }\end{array}$ & $\begin{array}{l}\text { Theoretical \& } \\
\text { Simulation }\end{array}$ & Rhino & $\begin{array}{l}\text { Grasshopper } \\
\text { DIVA }\end{array}$ & $\begin{array}{c}\text { EnergyPlus } \\
\text { Radiance Daysim }\end{array}$ & - \\
\hline
\end{tabular}




\section{Retrospective Analysis}

\subsection{Design Pattern}

Although each study case has fundamental differences in design parameters and project types, nevertheless, all collected samples showed a standard procedure. The mentioned energy-saving design research usually followed a similar design pattern, as shown in Figure 2. Energy-oriented design optimization is often broken down into multiple steps. With the start of the project, the design team needs to characterize the correlation between the surrounding environmental disturbance factors and the design objectives. Therefore, a large amount of detailed information needs to be entered. According to the customer's needs, a conceptual scheme to meet various design variables is proposed. The first two tasks are imported into a design generation engine that includes an energy simulation module to predict energy loads and form a design process file. At the core of the design engine, these simulations are purely digital, but the results are visualized (text or graphics) and can create a convincing basis for designers and customers. Energy optimization is such a complex task, not to mention creating a good indoor environment. In most cases, there is no guarantee that the computer can always simulate a perfect solution. Improving the design based on the analysis report is another important link in the entire process. The single optimal solution or multiple suboptimal solutions obtained through simulation constitute the optimized final design. The compromise in multiple scenarios is still the test facing the design team. It should be pointed out that there can be two special cases as follows: If the design targets are reached, the process is terminated immediately or if the design runs counter to the expected results, it is necessary to restart the solution evaluation and repeat the above steps (very rare, but still exist).

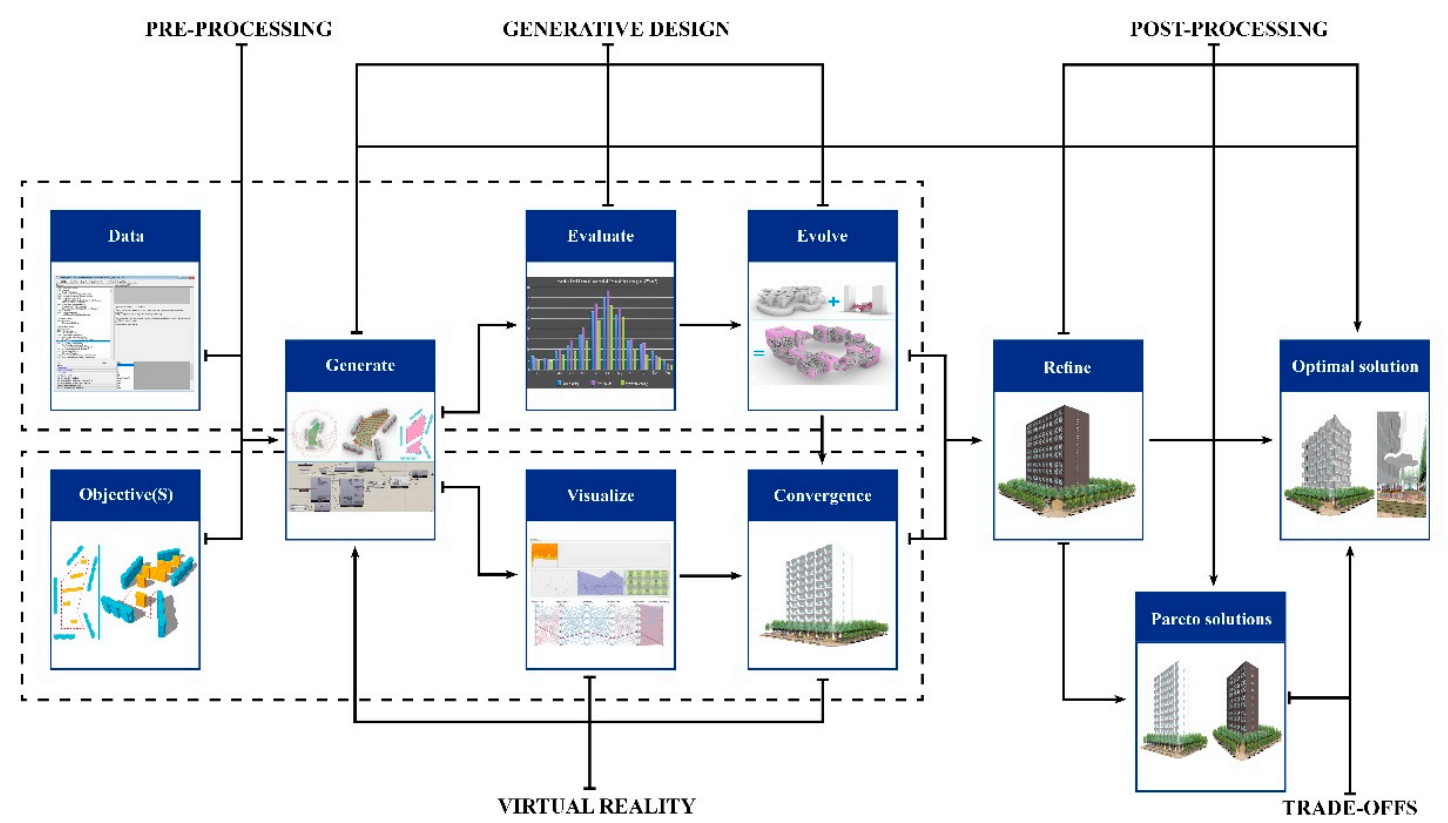

Figure 2. Performance-oriented design pattern. Adapted from [146].

With the replacement of hand-drawn technology by computer-aided design (CAD) and advanced information technology, the AEC industry has many means of obtaining information and data. Especially with the combination of optimization algorithm technology, it has the possibility of entering a new epoch of design process. Generating modules can help designers infer and optimize designs with visual results, orchestration schemes, and workflows. 


\subsection{Current Status and Features}

As the awareness of the potentially damaging effects of severe depletion of natural resources has increased, industries related to building design and management have responded by focusing on overall ecological and environmental performance while ensuring that functions and spaces are not overlooked. In this context, performance-driven design has become a new paradigm. Obviously, the statistical work on the literature is of great significance. The scope of this review covers all details of design optimization, including the subject area of research experts, project type, solution fineness, case study approach, optimization and performance objectives, energy simulation module, and optimization algorithm (Figure 3).
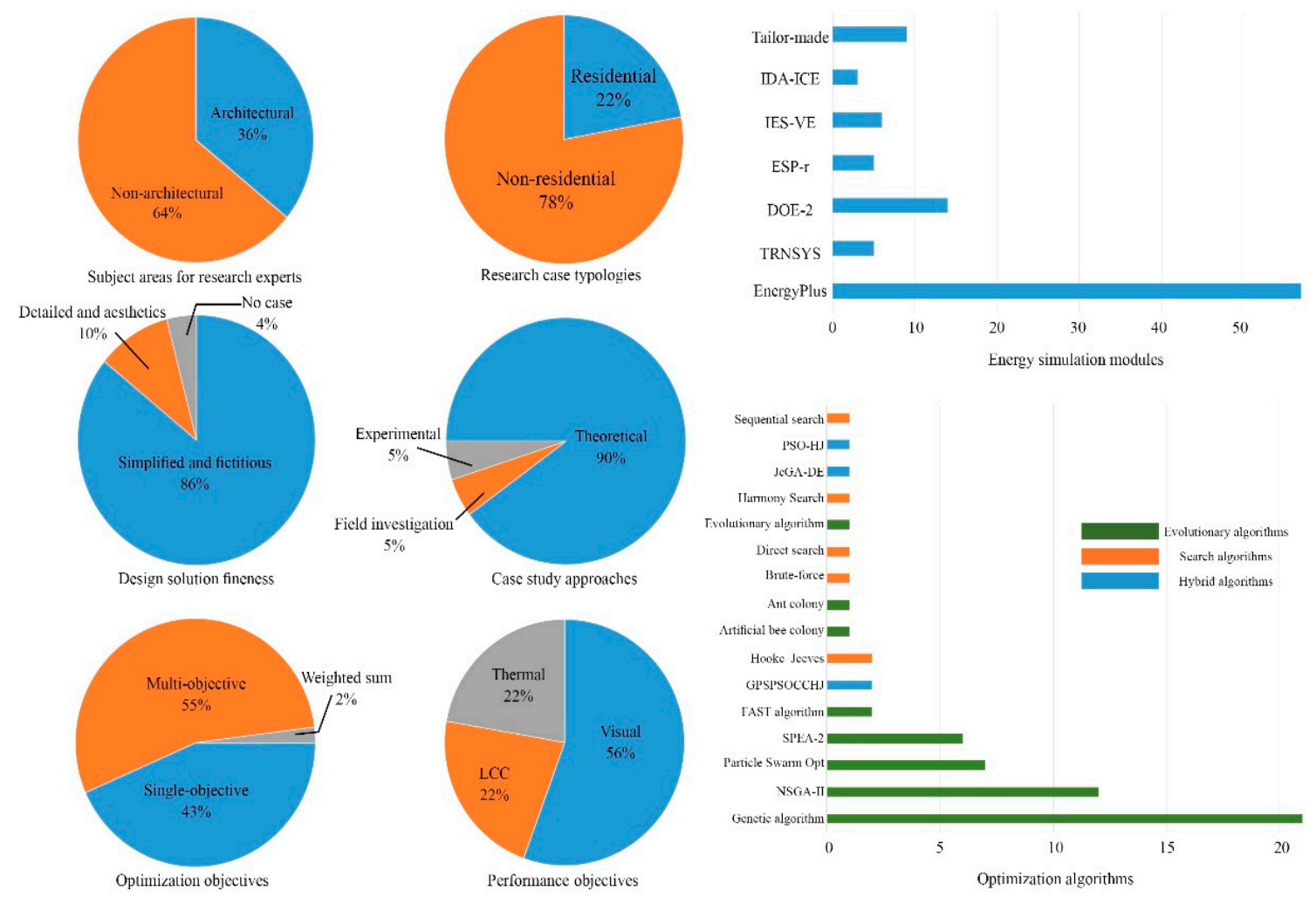

Figure 3. Graphical summary of all statistical works.

The first review node is the academic or technical background of all experts and scholars involved in this work, because the conclusion of this test can logically indicate the leading practitioners and research status of the topic. The data show that a total of 321 experts participated in 99 literature works reviewed. The affiliation of 100 authors indicated that they worked in the college or department of architecture, accounting for 31\%. In contrast, the remaining 221 confirmed that they came from energy, environment, and other related fields, accounting for $69 \%$. Conventional architectural design guidelines and methodologies cannot afford scientific calculation and quantification. Engineers and even computer technicians are currently leading the development of sustainable buildings. Most architects, as former industry leaders, lost initiative in the process.

The cases mentioned in the study are defined as two categories of residential buildings and nonresidential buildings according to service functions. Most of the published works (more than $80 \%$ ) focus on the energy use of nonresidential buildings. Since the increase in housing units and the improvement of living standards, the energy consumption related to the residential construction sector has skyrocketed in the past decade $[48,78,87]$. Unfortunately, this grim fact still seems to have failed to attract attention. The third content of the review is the fineness of the design scheme, which can clearly and reasonably judge the actual application of the technology and the impact on the 
architectural style in practical activities. Statistics show that only $10 \%$ of the design have developed detailed and unique architectural visual features, while simplified and virtual buildings account for $86 \%$. Design was absent in the remaining $4 \%$ of the work. On the one hand, such a low proportion of detailed design examples show that in most building practice, the actual promotion of this new technology has a huge gap as compared with the expected goal. On the other hand, it also confirms the inherent complexity and contradiction of the discipline of architecture. Based on the description of the design stage in the literature shown in Tables 1-3, the methods applied in the above studies were analyzed in depth. The results show that in the current stage of work, the method of establishing theoretical models that meet design goals and predicting energy data through simulation tools still dominates. Only $5 \%$ of the studies showed experimental models or reduced-scale conceptual models based on design intent during the process. Building a mockup room or full-scale design prototype after computational analysis and evaluating the actual energy consumption by simulating the on-site physical environment measurement data during the operation phase should have been very critical and convincing technology. It is regrettable that only a very small part of the research has covered this part of the content.

\subsection{Objectives and Optimization Techniques}

Starting a performance-oriented design optimization loop usually means that designers seek to minimize the cost of building initialization or operation while ensuring a comfortable indoor environment. In a sense, it also includes the long-term sustainable target of building life-cycle costs. Optimization goals are often described as the number and form of combinations of design variables. In general, straightforward solutions to a single objective or exploration of multiple complex problems are common definitions. According to the objective function defined by the design conditions, a single objective solution means seeking a global maximum or minimum. Forty-three percent the of studies addressed a single design problem. Instead, it is more common to require optimization of multiple objective functions simultaneously. Two other cases applied weighted sum methods to handle the multilevel decision problem and realized the combination of conflicting targets into a single solution $[65,76]$. Because the core topic of this review is building energy performance, the research content of all literatures is directly related to energy optimization. The most intuitive optimization goal is the annual energy cost. Moreover, the specific forms of performance objectives are diversified. Most of the studies are interested in maintaining visual comfort or lighting quality, and the related performance goals account for $56 \%$ of all the literature. It is to be observed that improving thermal comfort or reducing discomfort time, as well as minimizing operating and maintenance costs and reducing emissions are also two performance goals that have been mentioned many times, each occupying $22 \%$ of the research material.

Design boundaries are often composed of contradictory functional requirements. The process of solving one problem can cause the other objective functions to deteriorate. As a result, in order to locate these variables and perform targeted quantization and tradeoff of functions, algorithms are needed [31]. A set of solutions is generated by a multiobjective algorithm and plotted in the form of a curve called a Pareto frontier. The optimization algorithms shown in Figure 3 can be defined as three types [147]. The analysis data show that among all optimization problems, the evolutionary algorithm represented by genetic algorithm (GA) is used most frequently. The search algorithm represented by Hooke-Jeeves and the hybrid algorithm represented by PSO-HJ have also been found in research papers, but the frequency and number are far lower than the former category. It should be clear that not all design processes require the participation of optimization algorithms.

Energy simulation tools are vital modules in optimizing design workflows. They are widely used in energy calculation and decision analysis. EnergyPlus accounted for 57 of all 99 research papers, far ahead of other simulation engines. Similar tools used in other work include several types including TRNSYS. Custom-tailor based tools were also found in multiple records. The research project determines the completeness and complexity of these tools. It can be a complete application 
that is used to evaluate complex designs or it can be just a plugin to analyze a simplified benchmark model. Furthermore, most literature does not specify the tools used to implement three-dimensional (3D) models.

The most frequently used optimization algorithms and simulation tools mentioned earlier are not accidental. Some typical characteristics make it stand out in the field of practical application. Firstly, this tool has been identified as architect friendly for architects and engineers involved in decision making. Secondly, the technology transmits data from multiple work platforms and can quickly analyze and feedback input and output parameters. Finally, the software supports the comparison of multiple alternative models [30]. Taking the application of genetic algorithm and EnergyPlus in design optimization as an example, there are already many engineers familiar with easy-to-use work platforms coupled with energy simulation engines [34]. Matlab [148] is one of the most trusted products. Matlab developed by MathWorks combines multiple simulation tools for different research areas, and EnergyPlus for building energy simulation is one of them. The developed toolbox provides multiobjective optimization for linear or nonlinear problems. In addition, a custom programming toolkit for complex environments provides practitioners with ease-of-use. Encouraged by the development of well-developed commercial software, architects have also been assisted in promoting sustainable movements. At this point, Rhino [149] is a fairly mature open design software that integrates grasshopper [150] platform and also realizes parametric design through simple code. The Galapagos [151] module embedded in grasshopper uses genetic algorithm to optimize the objective function. Ladybug and Honeybee [152], a designer friendly plug-in, provides the service of energy consumption simulation in a rhino and grasshopper environment and allows users to work with the verified energy plus to get feedback.

\section{Industry Dividends and Potential Challenges}

\subsection{Heuristic Knowledge Base}

Currently, the AEC industry relies primarily on life-cycle approaches to make buildings more sustainable. It systematically quantifies the potential impact on the environment of a building from conceptual design to termination of service [153]. Traditional design methods tend to integrate quantifiable standards only in late stages. Contrary to earlier designs, evaluating the execution efficiency and applicability of a design mainly depends on the designer's self-knowledge of architecture and focuses more on a limited range of applications such as functionality and aesthetics. The evaluation of other properties (such as energy consumption, thermal comfort, and other related aspects) is usually delayed. Such methods have conspicuous limitations [154]. To mitigate the negative impact of buildings on the environment, it is particularly important to evaluate the energy consumption in the early stages of design [155]. As shown in Figure 4, the earlier the assessment, the more obvious the benefit. Full consideration is given to the possibility that the success of the solution is largely influenced by the choices made at the initial stage, so the involvement of a more professional comprehensive judgment process is necessary [156]. The paradox is that even at the conceptual scheme stage there are still too many parameters and information to be weighed. Although sensitivity analysis is available, it is considered to be too complicated, not to mention that paying too much attention to detailed variables can lead to a lack of creative work. In this case, applying an evaluation model based on a heuristic knowledge map can provide the necessary help.

As described in the previous section, only a small number of studies have developed a detailed scheme design and conducted experimental or field investigations, but it does not mean that the value and contribution of those theoretical studies can be easily denied. In a recent analysis, building orientation was considered one of the key optimization variables in the early design phase $[39,57,61,64,67]$. Optimal orientation can effectively reduce the negative effects of solar radiation, thereby correspondingly reducing the use of heating or cooling energy. The window-to-wall ratio is another important parameter that affects the initial design. A suitable size can compensate for 
insufficient ventilation and lighting. On the contrary, it causes unnecessary energy consumption. A lot of correlation knowledge emerged in this survey to make up for the data gap at this stage $[40,42,48,51,55,62,65]$. Changes in the data of reference models for different climate information are usually not recorded or tracked. The schematic diagram and its parameters determined by evidence-based methods are provided as default values to users and other tasks that require rapid simulation [49-51,59,66,73]. Obviously, all professional information acquired based on experimental experience, engineering judgment, a series of trials and errors, and catalog information also belongs to the core component of the expert knowledge system $[41,50,75,109,114,137,143]$. They are as effective as sensitivity and uncertainty analyses performed by users through manual intervention. A heuristic knowledge design approach that incorporates energy awareness is one of the direct benefits created by the above research. It is characterized by the establishment of a responsive knowledge base between design decisions and data lists. This is a highly interdependent process between contexts. Alternative tools combining rules of thumb and extensive knowledge accumulation allow designers to compress the search space for almost all the variables (shape, orientation, shading, site location, etc.) necessary for the design preprocessing stage [157]. This has greatly accelerated the process of building energy performance assessment.

Despite these advantages, the design guidance methods used by knowledge-inspired systems are based on generalized information from standard case studies. When designers need to apply such rules in complex nonstandard design environments, they cannot be applicable or even run counter to the idea. Therefore, extensive exchanges and consultations with engineering and technical personnel are necessary.

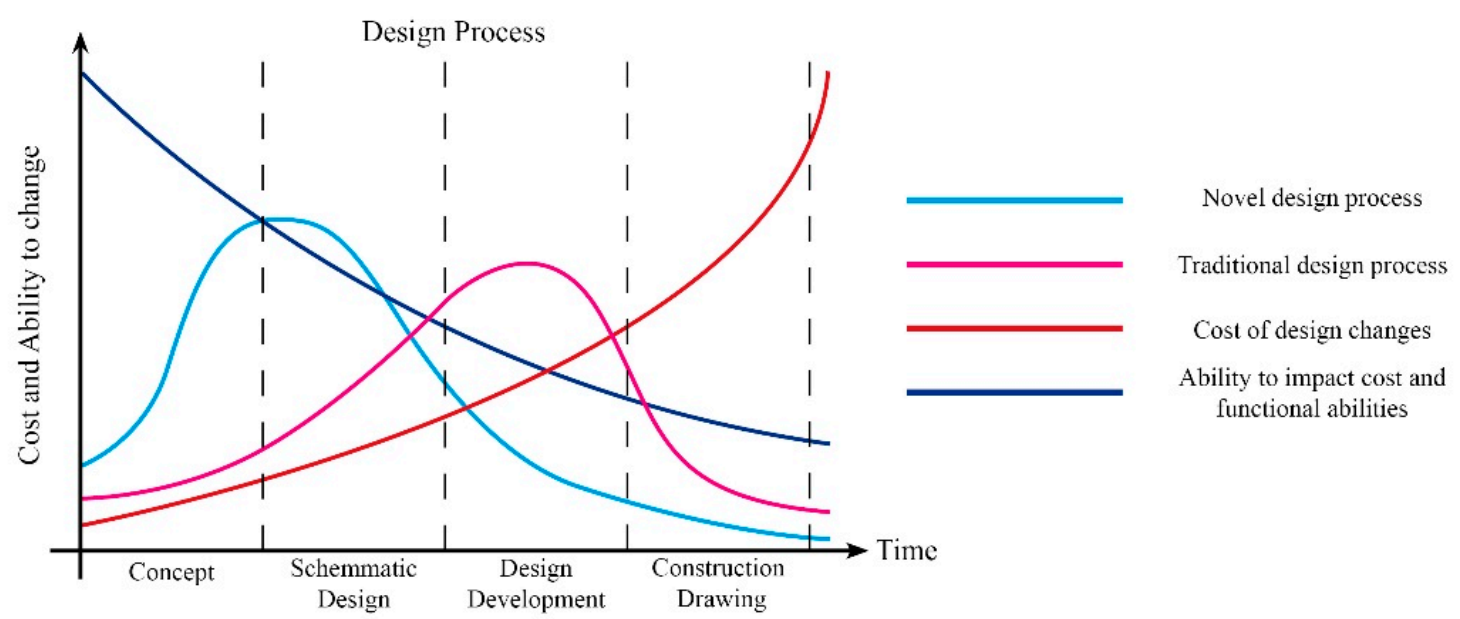

Figure 4. Time-utility distribution between sustainable and conventional processes. Adapted from [155].

\subsection{Expanding the Design Space}

The object-orientated design process integrating parametric information model technology, energy consumption simulation, and evolutionary algorithms is a rapidly emerging and popular method of sustainable building design. The purpose is to shift the workload to the early stages of design and to add a series of iterative activities in the scheme generation [158]. The conventional design process based on trial and error requires direct search of components with different configurations and parameters, and its ability to solve problems depends on the commonality between the problem and the existing design solution samples. It is not only time-consuming but also severely imprisons the innovation of design. In the design method of the correlation target variable and the optimization technology, the user can explicitly formalize the design concept and performance target by constructing a digital model in advance. The model is interpreted as a typical set of unrestricted instance variables according to the simulation experimental data, and each instance is determined by the model-specific independent variable selection, thereby expanding the expressiveness and scope of the constructed scheme [159]. 
This is why in the multiobjective design, all the options in the solution space are described as an approximate optimal solution in the design process in combination with the target requirements. In fact, one of the important effects of constraint variable agents is that transformations are performed, resulting in multiple combinations of the same component which automatically supports the generation of larger design variant sets within a controlled degree of freedom, providing a wider variety of alternative models and schemes [160]. Occupants' behavior has long been considered to be one of the uncertainties in improving building performance. The novel generative framework describes and models typical occupant behavior in buildings in various forms [161]. The simulation tool for coupled optimization algorithms allows users to write code to customize configuration files and control rules for device components and operating systems. A series of recent studies have shown that this technology can be applied in different scenarios including: reducing the air conditioning load of homes in humid climates [162], improving the efficiency of domestic hot water systems in hotel buildings [163], and properly controlling lighting equipment [164]. The industry dividend brought by a more flexible generative design method is to break the boundaries of different disciplines and overcome the limitations existing in the conventional design process. The expanded design space means enhanced access to performance-oriented tasks and strategies.

For designers, this promising practical technology has proven to be indirectly beneficial in highlighting the visual aspects of architecture and discussing new aesthetic standards. The design solution generated based on the innovative method not only quickly views different alternatives, but also realizes a geometric configuration where a large number of possible combinations of variables in the mapping domain cannot be conceived (Figure 5). In the novel process, rules are replaced with rule types, and a set of composable and navigable operators is used to generate a complex function space and geometry based on a unified parser [165], assisting decision makers by revealing new design directions while focusing on engineering performance standards, and also helping explore areas of design that have never been involved before. Whether a positive relationship exists between energy-driven design and architectural aesthetics is the starting point of this review. Over the past period, large-scale photovoltaic panels have ruggedly extended from the building roof to the site, and wrong demonstrations have appeared on both sides of the street. The correct design paradigm can eliminate public biases and misunderstandings about the formal characteristics of sustainable architecture.

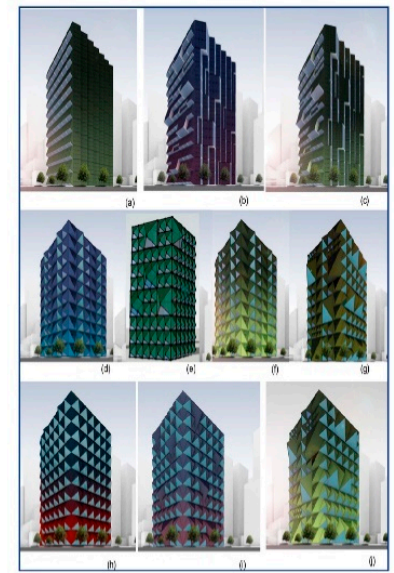

(a) Building envelope

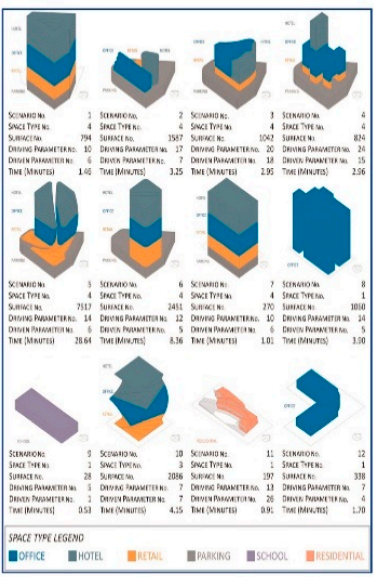

(b) Building geometry

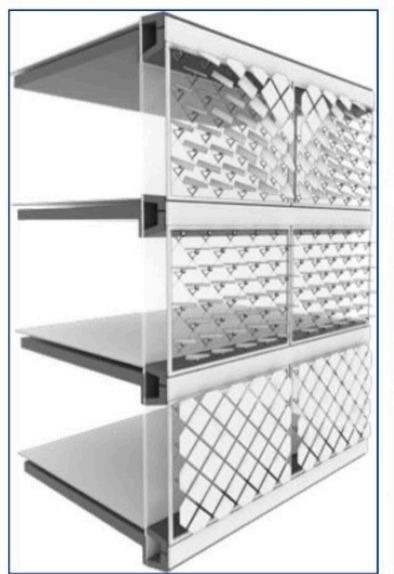

(c) BIPV shading system
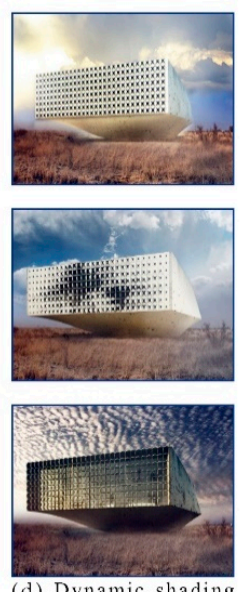

system

Figure 5. Studies on different components. (a) Building envelope [45]; (b) building geometry [95]; (c) BIPV shading system [143]; and (d) dynamic shading system [138].

Similar to the basic hierarchy of natural energy system classification, architecture is not an isolated object. The expanded design space is also suitable for diverse urban scenarios. A natural and harmonious urban environment is an important means to maintain ecological stability and building 
performance. A sustainable building should be understood as a trinity building, including the lowest energy consumption, the best urban environment, and excellent spatial quality. Architectural aesthetics and visual creativity are also the most important components. The loss of built environment quality attributes has no place in the true sustainable development of society [166].

\subsection{Tools, Skills, and Framework}

According to AIA Energy Modeling Guidelines, architects are the most suitable members to lead the process because they have experiences in integrating functions, spaces, and global systems [167]. From the literature, the dominance of architects seems to be challenged. Some have argued that architects do not have the ability to participate in the development or promotion of energy efficiency technology, but only the ultimate beneficiaries [22]. However, from the current research status, the engineer-led performance optimization design also has missing parts (discussed in Section 3). Objectively speaking, the existing conflicts and obstacles have complex and deep causes, and it is unfair to accuse any of them unilaterally. This is a challenge that industry stakeholders must deal with in the process of sustainable development that promotes integrated innovation.

The range of various building performance simulation (BPS) tools on the market can be divided into graphical user interface (GUI) tools and text user interface (TUI) tools according to user preferences (architects and engineers), underlying architecture, and operating logic [30]. The unfriendly architecture of BPS tools was considered to be an obstacle in previous work to enable performance-based design decisions, accelerate integration of energy performance assessment, and design processes. Currently, this missing piece has been made up for by the efforts of a large number of researchers. On the basis of a mature computing engine, a graphical interface simulation tool list has been developed, which extend the existing functions, and also meets the required speed and accuracy. However, practical applications show that discontinuities in the data file exchange format for different types of BPS tools and coupling barriers to optimize the interface between software packages are current urgent tasks [21,32]. The recommended effective solution is called middleware tool [33]. This associative design platform that provides multiple interactive forms has the powerful functions of directly operating geometric models, defining simulation conditions, and writing script algorithms [168]. The component's built-in hybrid programming language (HPL) module enables simultaneous transfer between visual and text programming interfaces. Modifications and extensions can be made by any architect, engineer, or third-party worker. Therefore, middleware cannot be simply defined as a converter of various types of data formats and input/output files between software platforms, but a system that can be deeply customized between the model level and the computing environment [169]. Unfortunately, it appears that the far-reaching impact of this technology has yet to spark widespread discussion.

Entering a new age, design has fundamentally changed in form and content. The skills gaps of architects and engineers have been highlighted. In the current context, not only do architects have to face fierce competition from their peers, it is crucial that the learning costs of most software used to optimize building performance remain expensive, let alone complicated knowledge of mathematics, environmental science, and computer science. In the same way, it is still a huge challenge for engineers. Most engineers admit that their professional background also does not include learning experience of architectural space and aesthetic criteria. Some scholars have suggested that the main pedagogical details of architectural education are questionable, and it has failed to develop students' ability to solve problems they could encounter in their careers [170]. In addition to a large amount of professional knowledge, decision makers are also required to keep an eye on the changing design paradigm to meet the public's consumer demand for architectural culture [171]. It needs to be acknowledged that these demands are made up of the numerous internal and external factors in sustainable design. Creative intuition, extensive interdisciplinary knowledge, organization, and coordination skills tend to determine that one of the two professional communities will become the supervisor of the integration project. 
With the emerging concept of green building and its potential, the business collaboration framework has changed. Design team members are facing new challenges to improve and refine workflow efficiency. Designers are required to describe and adjust the physical performance data of a conceptual solution from the perspective of energy conservation needs. If there are too many unidentified and ambiguous design variables, once the design iteration is performed, the associated man-hour cost of modification increases significantly. The innovative position of engineers as operators of computing models also needs to be guaranteed. When engineers are in the process of calibrating the calculation model, the risks associated with transmitting modification information that deviates from the design concept are more profound. Compared with the hierarchical and structural features of traditional workflow which are completely separated and unable to communicate and feedback, design team needs a novel hybrid driven framework. Architects and engineers no longer have clear business boundaries. As common stakeholders, they should have equal professional awareness in technical analysis and architectural design. The hybrid model needs to define more cross-disciplinary horizontal communication mechanisms, so that complex design problems can be solved collaboratively and efficiently.

\subsection{Calibration Model}

In general, the distinction between the calculated energy consumption in the building performance test phase and the field measurement data in the application phase is called the "performance gap" [24]. A great deal of research has become interested in this phenomenon. These studies explored this key issue from the perspectives of building energy and environmental monitoring [172,173], occupants' schedules and behavioral characteristics [168,174], building energy model verification and test benchmarks [20,26], and so on. Too many clues remind us that, for various reasons, deviations in building performance are theoretically inevitable. These studies provide valuable systematic knowledge to architects, engineers, and other decision makers. However, among the various bridging solutions presented, the establishment of a calibration model at the design stage is still missing.

The establishment of a calibration model should include two indispensable elements. Making prototype models of different metrics according to design decisions is the primary content of this work. As the project progresses, it eventually develops into a full-scale mockup (different from the digital model used for simulation) that can accurately restore all details. Subsequently, with the help of intelligent wireless monitoring equipment, a full range of on-site demonstrations are conducted. Unlike existing prediction models that only consider the annual energy consumption of a building, the biggest advantage of the calibration model is that it can monitor seasonal, monthly, daily, or even hourly changes in realistic scenarios. The recorded data can provide practical and effective solutions for improving the energy-saving performance of similar types of projects, especially in mixed climate backgrounds.

The working methods and collaboration mechanisms demonstrated by the Foster \& Partners team during the design of their client's European headquarters building project are instructive. The architect creatively designed a "breathing façade" combined with a natural ventilation system. In order to avoid an imbalance between the actual construction effect and the computer simulation result, the design team went through multiple experimental phases. First, a miniature model test of 1:100 was performed. The glass model was immersed in water and dye was injected to visualize the entire ventilation process. It was subsequently expanded to full-size mockups and real-world scenarios, allowing the introduction of air at the required temperature for relevant tests (Figure 6). The model was extensively tested and calibrated on each work area [166]. The building was rated BREEAM Outstanding, which can be largely attributed to the tireless efforts of research and testing. 


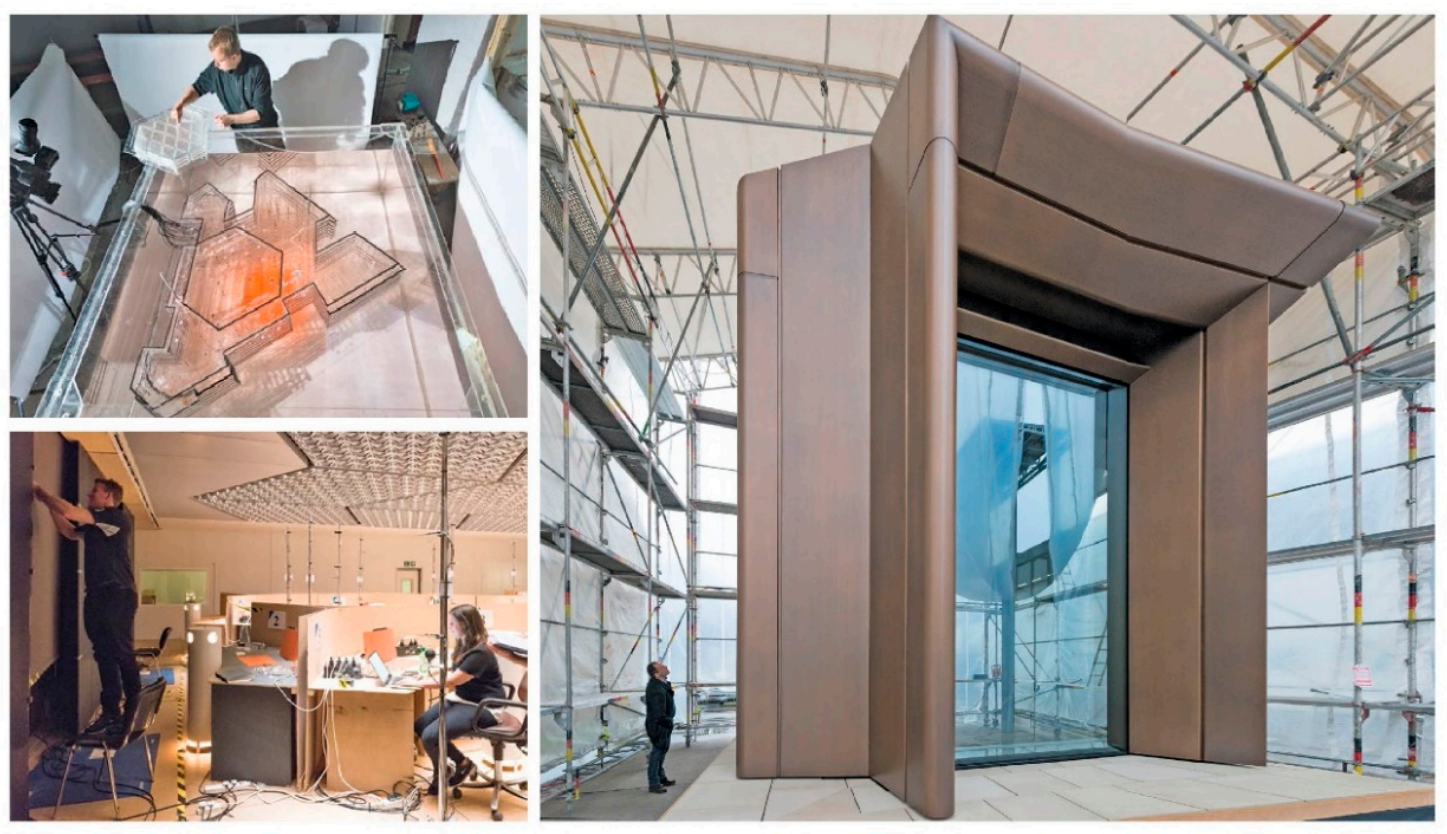

Figure 6. Prototype testing [175].

\section{Conclusions and Future Work}

\subsection{Conclusions}

In architectural discourse, the same vocabulary used to describe performance has been shared for a long time, but the content it represents varies dynamically in different contexts. This review takes the correlation hypothesis between performance-oriented design optimization and architectural aesthetics as the starting point and focuses on the opportunities and challenges faced by architects and other professionals in the process of design paradigm changes. From a large number of published papers and reports, 99 were recommended as core materials. Through combing the work accumulated in this research field for nearly three decades, the in-depth analysis and discussion of general processes, optimization and performance objectives, simulation modules, and optimization algorithms were conducted.

Performance-oriented architectural design is undoubtedly a complex technical system involving multiple disciplines. But the generative design patterns established by the researchers presented in all cases are consistent. It contains a number of closely connected components such as building information model platform, energy simulation engine, and optional optimization algorithm module (Figure 2). In addition to the design objectives and parameters specified by the decision makers during the solution generation process, the rest is highly integrated and dynamic.

With rapid changes in design patterns, the traditional role assignments of architects, engineers, and other professionals in decision-making teams have shifted significantly. Only $31 \%$ of the participants in the study identified themselves as architects, which triggered a series of chain reactions. The vast majority of projects and studies (over $85 \%$ ) only provided theoretical calculation models or simplified design solutions that abandon architectural style and visual characteristics. Only $5 \%$ of the work showed experimental conceptual models or micro-scale prototype models made according to design intent.

To date, more attention has been given to multiobjective optimization. In addition to building energy performance (annual energy consumption), research has generated great interest in visual performance (indoor lighting environment) or thermal performance (comfort index) and life cycle costs. In order to achieve multiobjective optimization, evolutionary algorithms, search algorithms, and hybrid algorithms are widely used. In these directories, the family of evolutionary algorithms represented by genetic algorithms occupy an overwhelming advantage. Correspondingly, EnergyPlus has become 
the most commonly used energy calculation engine in performance-oriented building design. Other tailored simulation tools have also been discovered. Current trends reveal that selected tools must undergo a dual assessment of timeliness and robustness. The proposed survey shows that as compared with conventional design strategies integrated optimization has stimulated extensive discussions on architectural design paradigms. All performance-based analysis data, simulation models, and evaluation results are assembled into an expert knowledge base that supports energy-conscious design and optimization. The heuristic method expresses information characteristics related to energy consumption in the form of design variables (parameters) and their relationships. Energy-saving rules are applied in benchmarking models. Decision makers enable expert knowledge and empirical judgment based on context sensitivity to assign values to the default information, thereby effectively improving the overall execution of the design.

The second benefit is directly related to the holistic consideration of form and energy. Integrated optimization undoubtedly promotes the breadth and depth of design scope. The building information model coupled with energy consumption simulation and multiobjective optimization algorithm can quickly realize visualization of different scenarios. Alternate combinations based on multiple variables have resulted in many unpredicted geometric configurations in the generated design. Both factors help expand the space for viable design solutions, as well as reveal architectural styles and features that were not previously expressed.

Recent developments in sustainable movements have inspired innovations and challenges in the applications and technologies that support the AEC industry. In most scenarios, geometric models are expected to exchange data with computational and algorithmic models in both directions, but this situation rarely occurs in dynamic coupling programs. The extreme lack of middleware for unifying software environment interfaces and exchanging data formats is the primary obstacle faced. As the design paradigm shifted, architects and engineers discovered what was missing in their reserves of expertise and vocational skills. These factors greatly limit the applicability of the technology in real-world practice. Moreover, the huge differences in target motivation, operating regulations, and evaluation criteria between the two groups are also issues that cannot be ignored in the working framework.

In order to solve the aforementioned performance gap, the establishment of extensive calibration models is also an indispensable part of the design process. Developing a full-scale mockup that reflects design intent and details is considered to be an extremely important step. Accurate data based on comprehensive on-site monitoring was eventually used to evaluate the objective results of the design scheme under changing climate conditions.

\subsection{Future Work}

Despite considerable research on building energy performance optimization, there are still unsolved issues before it can be widely used in the AEC sector to form incentives and quantification criteria. Therefore, the following future work is recommended:

- One of the most pressing issues is to raise awareness of planners and architects to consider the effectiveness and necessity of energy consumption and its expected impact on sustainable development. An insightful design tool based on pattern language is thought to have a positive impact on the design process. The scientific discourse on language and its systematic use in the design process has a strong tradition in planning and architecture. The language tool describes the responsive knowledge of the mapped energy as a matrix diagram nested within each other. Abstract architectural physics phenomena are transformed into concrete design strategies. The essential goal of energy model language is not to negate and abandon existing technologies. Instead, it is similar to an extension package loaded in a tool kit, which is responsive to the environment.

- From the perspective of pedagogy, performance-based architectural design is a method that relies on professional skills and tacit knowledge to solve comprehensive design problems that combine 
the physical environment and material quality. On the basis of this prerequisite, vocational education in architecture should start to improve from both the basic curriculum and design training. In the process of shaping the students' theoretical system, interdisciplinary knowledge should be gradually connected at different stages. In design training, on the one hand, students need to be guided and encouraged to use computer programs to carry out a holistic analysis of the solution. Thereby obtaining fairly reliable data and parameters. On the other hand, it is necessary to advocate and highlight the creative part of the design, and therefore prevent candidates from falling into the persistent misunderstanding of technology-only thinking.

- Although a general design generation model has been developed, its accuracy in predicting building energy consumption simulation still needs to be rigorously evaluated. To bridge the gap in building performance, a promising approach is to build a hybrid model that fully reflects the behavior of the occupants. In this project, simulation engines and optimization algorithms were not selected as the focus of work. Data acquisition methods combining physical environment and socioeconomic factors are research directions. A holistic approach and roadmap should be used to determine the appropriate sample size, instrument deployment, and monitoring period, which is a top priority.

Author Contributions: Conceptualization, S.L. and C.P.; methodology, C.P.; validation, S.L. and L.L.; formal analysis, S.L.; investigation, L.L.; data curation, S.L.; writing-original draft preparation, S.L.; writing-review and editing, S.L. and C.P.; visualization, S.L.; supervision, C.P.; project administration, C.P. All authors have read and agreed to the published version of the manuscript.

Funding: This study was supported by the Ministry of Science and Technology of the Peoples Republic of China (Key Projects of Technological Innovation for Green Livable Village, grant no. 2019YFD1100805), and the Fundamental Research Funds for the Central Universities and Postgraduate Research \& Practice Innovation Program of Jiangsu Province (grant no. KYCX17_0109).

Acknowledgments: Any opinions, findings, conclusions, or recommendations expressed in this study are those of the authors and do not necessarily reflect the views of the committee.

Conflicts of Interest: The authors declare no conflict of interest.

\section{References}

1. Hensel, M. Performance-Oriented Architecture: Rethinking Architectural Design and the Built Environment; John Wiley \& Sons Ltd.: West Sussex, UK, 2013; p. 13.

2. Ching, F.D.K. Architecture: Form, Space, E Order, 4th ed.; John Wiley \& Sons: Hoboken, NJ, USA, 2015; pp. 306-348.

3. Wilde, P.D. Building Performance Analysis; John Wiley \& Sons: Hoboken, NJ, USA, 2018; pp. $15-45$.

4. WCOEAD. Our Common Future. 1987. Available online: http://www.un-documents.net/wced-ocf.htm (accessed on 18 November 2019).

5. BREEAM, ESS SD 5076 BREEAM UK New Construction-Non-Domestic Buildings (Wales). Technical Manual. Issue 5.0-2014. BRE Global Ltd. Available online: https://www.thenbs.com/PublicationIndex/documents/ details?Pub=BREGLOBAL\&DocID=317523 (accessed on 18 November 2019).

6. LEED. Available online: http://leed.usgbc.org/leed.html?gclid=COvH1POp6swCFdYK0wodfCkK1g (accessed on 18 November 2019).

7. Nielsen, A.N. Early stage decision support for sustainable building renovation-A review. Build. Environ. 2016, 103, 165-181. [CrossRef]

8. MOHURD. Available online: http://www.mohurd.gov.cn/wjfb/201905/t20190530_240717.html (accessed on 18 November 2019).

9. Building Energy Software Tools (BEST) Directory. Available online: https://www. buildingenergysoftwaretools.com/ (accessed on 18 November 2019).

10. Shi, X. Performance-based and performance-driven architectural design and optimization. Front. Archit. Civ. Eng. 2010, 4, 512-518. [CrossRef]

11. Braham, W.W. Architecture, style, and power: The Work of Civilization. In Architecture and Energy Performance and Style; Braham, W.W., Willis, D., Eds.; Routledge: New York, NY, USA, 2013; p. 37. 
12. Olgyay, V. Design with Climate: Bioclimatic Approach to Architectural Regionalism; Princeton University Press: Princeton, NJ, USA, 1963; pp. 3-10.

13. Hemsath, T.L.; Bandhosseini, K.A. Sensitivity analysis evaluating basic building geometry's effect on energy use. Renew. Energy 2015, 76, 526-538. [CrossRef]

14. Soutullo, S.; Giancola, E.; Franco, J.M.; Boton, M.; Ferrer, J.A.; Heras, M.R. New simulation platform for the rehabilitation of residential buildings in Madrid. Energy Procedia 2017, 122, 817-822. [CrossRef]

15. Soutullo, S.; Giancola, E.; Heras, M.R. Dynamic energy assessment to analyze different refurbishment strategies of existing dwellings placed in Madrid. Energy 2018, 152, 1011-1023. [CrossRef]

16. Sánchez, M.N.; Giancola, E.; Blanco, E.; Soutullo, S.; Suárez, M.J. Experimental Validation of a Numerical Model of a Ventilated Façade with Horizontal and Vertical Open Joints. Energies 2020, 13, 146. [CrossRef]

17. Pacheco, R.; Ordóñez, J.; Martínez, G. Energy efficient design of building: A review. Renew. Sustain. Energy Rev. 2016, 16, 3559-3573. [CrossRef]

18. Evins, R. A review of computational optimisation methods applied to sustainable building design. Renew. Sustain. Energy Rev. 2013, 22, 230-245. [CrossRef]

19. Machairas, V.; Tsangrassoulis, A.; Axarli, K. Algorithms for optimization of building design: A review Renew. Renew. Sustain. Energy Rev. 2014, 31, 101-112. [CrossRef]

20. Harish, V.S.K.V.; Kumar, A. A review on modeling and simulation of building energy systems. Renew. Sustain. Energy Rev. 2016, 56, 1272-1292. [CrossRef]

21. Østergård, T.; Jensen, R.L.; Maagaard, S.E. Building simulations supporting decision making in early design-A review. Renew. Sustain. Energy Rev. 2016, 61, 187-201. [CrossRef]

22. Shi, X.; Tian, Z.C.; Chen, W.Q.; Si, B.H.; Jin, X. A review on building energy efficient design optimization rom the perspective of architects. Renew. Sustain. Energy Rev. 2016, 65, 872-884. [CrossRef]

23. Amasyali, K.; Gohary, N.M.E. A review of data-driven building energy consumption prediction studies. Renew. Sustain. Energy Rev. 2018, 18, 1192-1205. [CrossRef]

24. Shi, X.; Si, B.H.; Zhao, J.S.; Tian, Z.C.; Wang, C.; Jin, X.; Zhou, X. Magnitude, Causes, and Solutions of the Performance Gap of Buildings: A Review. Sustainability 2019, 11, 937. [CrossRef]

25. Tian, Z.C.; Zhang, X.K.; Jin, X.; Zhou, X.; Si, B.H.; Shi, X. Towards adoption of building energy simulation and optimization for passive building design: A survey and a review. Energy Build. 2018, 158, 1306-1316. [CrossRef]

26. Foucquier, A.; Robert, S.; Suard, F.; Stéphan, L.; Jay, A. State of the art in building modelling and energy performances prediction: A review. Renew. Sustain. Energy Rev. 2013, 23, 272-288. [CrossRef]

27. Westermann, P.; Evins, R. Surrogate modelling for sustainable building design-A review. Energy Build. 2019, 198, 170-186. [CrossRef]

28. Kamel, E.; Memari, A.M. Review of BIM's application in energy simulation: Tools, issues, and solutions. Autom. Constr. 2019, 97, 164-180. [CrossRef]

29. Wen, L.W.; Hiyama, K. A review: Simple tools for evaluating the energy performance in early design stages. Procedia Eng. 2016, 146, 2-39. [CrossRef]

30. Han, T.; Huang, Q.; Zhang, A.X.; Zhang, Q. Simulation-Based Decision Support Tools in the Early Design Stages of a Green Building-A Review. Sustainability 2018, 10, 3696. [CrossRef]

31. Attia, S.; Hamdy, M.; O’Brien, W.; Carlucci, S. Assessing gaps and needs for integrating building performance optimization tools in net zero energy buildings design. Energy Build. 2013, 60, 110-124. [CrossRef]

32. Nguyen, A.T.; Reiter, S.; Rigo, P. A review on simulation-based optimization methods applied to building performance analysis. Appl. Energy 2014, 113, 1043-1058. [CrossRef]

33. Negendahl, K. Building performance simulation in the early design stage: An introduction to integrated dynamic models. Autom. Constr. 2015, 54, 39-53. [CrossRef]

34. Kheiri, F. A review on optimization methods applied in energy-efficient building geometry and envelope design. Renew. Sustain. Energy Rev. 2018, 92, 897-920. [CrossRef]

35. Al-Masrani, S.M.; Al-Obaidi, K.M. Dynamic shading systems: A review of design parameters, platforms and evaluation strategies. Autom. Constr. 2019, 102, 195-216. [CrossRef]

36. Aleksandrowicz, O. appearance and performance: Israeli building climatology and its effect on local architectural practice (1940-1977). Archit. Sci. Rev. 2017, 60, 371-381. [CrossRef]

37. Leatherbarrow, D.; Wesley, R. Performance and style in the work of olgyay and olgyay. ARQ. 2014, 18, 167-176. [CrossRef] 
38. Ghisi, E.; Tinker, J. Optimising Energy Consumption in Offices as a Function of Window Area and Room Size. In Proceedings of the 7th International IBPSA Conference, Rio de Janeiro, Brazil, 13-15 August 2001.

39. Košira, M.; Gostiša, T.; Kristl, Ž. Influence of architectural building envelope characteristics on energy performance in Central European climatic conditions. J. Build. Eng. 2018, 15, 278-288. [CrossRef]

40. Wen, L.W.; Hiyama, K.; Koganei, M. A method for creating maps of recommended window-to-wall ratios to assign appropriate default values in design performance modeling: A case study of a typical office building in Japan. Energy Build. 2017, 145, 304-317. [CrossRef]

41. Trebilcock, M.; Piderit, B.; Soto, J.; Figueroa, R. A parametric analysis of simple passive strategies for improving thermal performance of school classrooms in Chile. Archit. Sci. Rev. 2016, 59, 385-399. [CrossRef]

42. Leskovar, V.Ž.; Premrov, M. An approach in architectural design of energy-efficient timber buildings with a focus on the optimal glazing size in façade. Energy Build. 2011, 43, 3410-3418. [CrossRef]

43. Krietemeyer, E.A.; Smith, S.I.; Dyson, A.H. Dynamic Window Daylighting Systems: Electropolymeric Technology for Solar Responsive Building Envelopes. In Proceedings of the Electroactive Polymer Actuators and Devices (EAPAD), San Diego, CA, USA, 7-10 March 2011.

44. Hachem, C.; Elsayed, M. Patterns of façade system design for enhanced energy performance of multistory buildings. Energy Build. 2016, 130, 366-377. [CrossRef]

45. Hachem, C. Multistory building envelope: Creative design and enhanced performance. Sol. Energy 2018, 159, 710-721. [CrossRef]

46. Ercan, B.; Ozkan, S.T.E. Performance-based parametric design explorations: A method for generating appropriate building components. Design Stud. 2015, 38, 33-53. [CrossRef]

47. Zhang, A.X.; Bokel, R.; Dobbelsteen, A.V.D.; Sun, Y.C.; Huang, Q.; Zhang, Q. Optimization of thermal and daylight performance of school buildings based on a multi-objective genetic algorithm in the cold climate of China. Energy Build. 2017, 139, 371-384. [CrossRef]

48. Toutou, A.; Fikry, M.; Mohamed, W. The parametric based optimization framework daylighting and energy performance in residential buildings in hot arid zone. Alex. Eng. J. 2018, 57, 3595-3608. [CrossRef]

49. Lauridsen, P.K.B.; Petersen, S. Integrating Indoor Climate, Daylight and Energy Simulations in Parametric Models and Performance-Based Design. In Proceedings of the 3rd International Workshop on Design in Civil and Environmental Engineering (DCCE3), Kongens Lyngby, Denmark, 21-23 August 2014; pp. 111-118.

50. Chi, D.A.; Moreno, D.; Navarro, J. Correlating daylight availability metric with lighting, heating and cooling energy consumptions. Build. Environ. 2018, 132, 170-180. [CrossRef]

51. Si, B.H.; Tian, Z.C.; Chen, W.Q.; Jin, X.; Zhou, X.; Shi, X. Performance Assessment of Algorithms for Building Energy Optimization Problems with Different Properties. Sustainability 2019, 11, 18. [CrossRef]

52. Caldas, L.G.; Norford, L.K. A design optimization tool based on a genetic algorithm. Autom. Constr. 2002, 11, 173-184. [CrossRef]

53. Ma, Q.S.; Fukuda, H. Parametric office building for daylight and energy analysis in the early design stages. Procedia Soc. Behav. Sci. 2016, 216, 818-828.

54. Negendahl, K.; Nielsen, T.R. Building energy optimization in the early design stages: A simplified method. Energy Build. 2015, 105, 88-99. [CrossRef]

55. Wright, J.; Mourshed, M. Geometric optimization of fenestration. In Proceedings of the 11th International IBPSA Conference, Glasgow, UK, 27-30 July 2009.

56. Glassman, E.J.; Reinhart, C. Façade Optimization Using Parametric Design and Future Climate Scenarios. In Proceedings of the 13th Conference of International Building Performance Simulation Association, Chambéry, France, 26-28 August 2013; pp. 1585-1592.

57. Delgarm, N.; Sajadi, B.; Delgarm, S. Multi-objective optimization of building energy performance and indoor thermal comfort: A new method using artificial bee colony (ABC). Energy Build. 2016, 131, 42-53. [CrossRef]

58. Rapone, G.; Saro, O. Optimisation of curtain wall facades for office buildings by means of PSO algorithm. Energy Build. 2012, 45, 189-196. [CrossRef]

59. D’Cruz, N.; Radford, A.D.; Gero, J.S. Pareto Optimization Problem Formulation for Building Performance and Design. Eng. Optim. 1983, 7, 17-33. [CrossRef]

60. Ochoa, C.E.; Aries, M.B.C.; Loenen, E.J.V.; Hensen, J.L.M. Considerations on design optimization criteria for windows providing low energy consumption and high visual comfort. Appl. Energy 2012, 95, 238-245. [CrossRef] 
61. Grygierek, J.F.; Grygierek, K. Multi-Variable Optimization of Building Thermal Design Using Genetic Algorithms. Energies 2017, 10, 1570. [CrossRef]

62. Zhai, Y.N.; Wang, Y.; Huang, Y.Q.; Meng, X.J. A multi-objective optimization methodology for window design considering energy consumption, thermal environment and visual performance. Renew. Energy 2019, 134, 1190-1199. [CrossRef]

63. Lartigue, B.; Lasternas, B.; Loftness, V. Multi-objective optimization of building envelope for energy consumption and daylight. Indoor Built. Environ. 2014, 23, 70-80. [CrossRef]

64. Futrell, B.J.; Ozelkan, E.C.; Brentrup, D. Bi-objective optimization of building enclosure design for thermal and lighting performance. Build. Environ. 2015, 92, 591-602. [CrossRef]

65. Delgarm, N.; Sajadi, B.; Kowsary, F.; Delgarm, S. Multi-objective optimization of the building energy performance: A simulation-based approach by means of particle swarm optimization (PSO). Appl. Energy 2016, 170, 293-303. [CrossRef]

66. Gou, S.Q.; Nik, V.M.; Scartezzini, J.L.; Zhao, Q.; Li, Z.R. Passive design optimization of newly-built residential buildings in Shanghai for improving indoor thermal comfort while reducing building energy demand. Energy Build. 2018, 169, 484-506. [CrossRef]

67. Echenagucia, T.M.; Capozzoli, A.; Cascone, Y.; Sassone, M. The early design stage of a building envelope: Multi-objective search through heating, cooling and lighting energy performance analysis. Appl. Energy 2015, 154, 577-591. [CrossRef]

68. Hani, A.; Koiv, T.A. Optimization of Office Building Façades in a Warm Summer Continental Climate. Smart Grid Renew. Energy 2012, 3, 222-230. [CrossRef]

69. Khatami, M.; Kordjamshidi, M.; Mohammad, K.B.; Zolfaghari, A. Design Optimization of Glazing Façade by Using the GPSPSOCCHJ Algorithm. In Proceedings of the 30th international PLEA conference, Ahmedabad, India, 16-18 December 2014.

70. Ferrara, M.; Filippi, M.; Sirombo, E.; Cravino, V. A Simulation-Based Optimization Method for the Integrative Design of the Building Envelope. Energy Procedia 2015, 78, 2608-2613. [CrossRef]

71. Carlucci, S.; Pagliano, L. An optimization procedure based on thermal discomfort minimization to support the design of comfortable net zero energy buildings. In Proceedings of the 13th Conference of International Building Performance Simulation Association, Chambéry, France, 26-28 August 2013; pp. 3690-3697.

72. Carlucci, S.; Cattarin, G.; Causone, F.; Pagliano, L. Multi-objective optimization of a nearly zero-energy building based on thermal and visual discomfort minimization using an on-dominated sorting genetic algorithm (NSGA-II). Energy Build. 2015, 104, 378-394. [CrossRef]

73. Yu, W.; Li, B.Z.; Jia, H.Y.; Zhang, M.; Wang, D. Application of multi-objective genetic algorithm to optimize energy efficiency and thermal comfort in building design. Energy Build. 2015, 88, 135-143. [CrossRef]

74. Salimi, S.; Mawlan, M.; Hammad, A. Performance analysis of simulation-based optimization of construction projects using High Performance Computing. Autom. Constr. 2018, 87, 158-172. [CrossRef]

75. Bamdada, K.; Cholette, M.E.; Guan, L.; Bell, J. Ant colony algorithm for building energy optimisation problems and comparison with benchmark algorithms. Energy Build. 2017, 154, 404-414. [CrossRef]

76. Si, B.H.; Wang, J.G.; Yao, X.Y.; Shi, X.; Jin, X.; Zhou, X. Multi-objective optimization design of a complex building based on an artificial neural network and performance evaluation of algorithms. Adv. Eng. Inform. 2019, 40, 93-109. [CrossRef]

77. Nguyen, A.T.; Reiter, S. Optimum Design of Low-Cost Housing in Developing Countries Using Nonsmooth Simulation-Based Optimization. In Proceedings of the 28th international PLEA conference, Lima, Peru, 7-9 November 2012.

78. Ihm, P.; Krarti, M. Design optimization of energy efficient residential buildings in Tunisia. Build. Environ. 2012, 58, 81-90. [CrossRef]

79. Sadineni, S.B.; Madala, S.; Boehm, R.F. Passive building energy savings: A review of building envelope components. Renew. Sustain. Energy Rev. 2011, 15, 3617-3631. [CrossRef]

80. Al-Homoud, M.S. A Systematic Approach for the Thermal Design Optimization of Building Envelopes. J. Build. Phys. 2005, 29, 95-119. [CrossRef]

81. Rashdi, W.S.S.W.M.; Embi, M.R. Analysing Optimum Building Form in Relation to Lower Cooling Load. Procedia Soc. Behav. Sci. 2016, 222, 782-790. [CrossRef]

82. Brown, N.C.; Mueller, C.T. Design for structural and energy performance of long span buildings using geometric multi-objective optimization. Energy Build. 2016, 127, 748-761. [CrossRef] 
83. Shaeri, J.; Yaghoubi, M.; Habibi, A.; Chokhachian, A. The Impact of Archetype Patterns in Office Buildings on the Annual Cooling, Heating and Lighting Loads in Hot-Humid, Hot-Dry and Cold Climates of Iran. Sustainability 2019, 11, 311. [CrossRef]

84. Youssef, M.A.A.; Zhai, Z.Q.J.; Reffat, R.M. Genetic algorithm based optimization for photovoltaics integrated building envelope. Energy Build. 2016, 127, 627-636. [CrossRef]

85. Waibel, C.; Evins, R.; Carmeliet, J. Co-simulation and optimization of building geometry and multi-energy systems: Interdependencies in energy supply, energy demand and solar potentials. Appl. Energy 2019, 242, 1661-1682. [CrossRef]

86. Capeluto, I.G. Energy performance of the self-shading building envelope. Energy Build. 2003, 35, 327-336. [CrossRef]

87. Gan, V.J.L.; Wong, H.K.; Tse, K.T.; Cheng, J.C.P.; Lo, I.M.C.; Chan, C.M. Simulation-based evolutionary optimization for energy-efficient layout plan design of high-rise residential buildings. J. Clean. Prod. 2019, 231, 1375-1388. [CrossRef]

88. Kämpf, J.H.; Robinson, D. Optimisation of building form for solar energy utilisation using constrained evolutionary algorithms. Energy Build. 2010, 42, 807-814. [CrossRef]

89. Hemsath, T.L.; Bandhosseini, K.A. Building Design with Energy Performance as Primary Agent. Energy Procedia 2015, 78, 3049-3054. [CrossRef]

90. Dubrow, D.T.; Krarti, M. Genetic-algorithm based approach to optimize building envelope design for residential buildings. Build. Environ. 2010, 45, 1574-1581. [CrossRef]

91. Asadi, S.; Amiri, S.S.; Mottahedi, M. On the development of multi-linear regression analysis to assess energy consumption in the early stages of building design. Energy Build. 2014, 85, 246-255. [CrossRef]

92. Chen, K.W.; Janssen, P.; Schlueter, A. Multi-objective optimisation of building form, envelope and cooling system for improved building energy performance. Autom. Constr. 2018, 94, 449-457. [CrossRef]

93. Li, Z.W.; Chen, H.Z.; Lin, B.R.; Zhu, Y.X. Fast bidirectional building performance optimization at the early design stage. Build. Simul. China 2018, 11, 647-661. [CrossRef]

94. Lin, S.H.E.; Gerber, D.J. Designing in performance: A framework for evolutionary energy performance feedback in early stage design. Autom. Constr. 2014, 38, 59-73. [CrossRef]

95. Gerber, D.J.; Lin, S.H.E. Designing in complexity: Simulation, integration, and multidisciplinary design optimization for architecture. Simulation 2014, 90, 936-959. [CrossRef]

96. Konis, K.; Gamas, A.; Kensek, K. Passive performance and building form: An optimization framework for early-stage design support. Sol. Energy 2016, 125, 161-179. [CrossRef]

97. Granadeiro, V.; Duarte, J.P.; Correia, J.R.; Leal, V.M.S. Building envelope shape design in early stages of the design process: Integrating architectural design systems and energy simulation. Autom. Constr. 2013, 32, 196-209. [CrossRef]

98. Caldas, L.G. Three-Dimensional Shape Generation of Low-Energy Architectural Solutions using Pareto Genetic Algorithms. In Proceedings of the 23rd eCAADe Conference, Lisbon, Portugal, 21-24 September 2005; pp. 647-654.

99. Caldas, L.G. Generation of energy-efficient architecture solutions applying GENE_ARCH: An evolution-based generative design system. Adv. Eng. Inform. 2008, 22, 59-70. [CrossRef]

100. Yi, Y.K.; Malkawi, A.M. Optimizing building form for energy performance based on hierarchical geometry relation. Autom. Constr. 2009, 18, 825-833. [CrossRef]

101. Jin, J.T.; Jeong, J.W. Optimization of a free-form building shape to minimize external thermal load using genetic algorithm. Energy Build. 2014, 85, 473-482. [CrossRef]

102. Agirbas, A. Performance-based design optimization for minimal surface based form. Archit. Sci. Rev. 2018, 61, 384-399. [CrossRef]

103. Conti, Z.X.; Shepherd, P.; Richens, P. Multi-Objective Optimisation of Building Geometry for Energy Consumption and View Quality. In Proceedings of the 33rd eCAADe Conference, Vienna, Austria, 16-18 September 2015.

104. Marks, W. Multicriteria Optimisation of Shape of Energy-Saving Buildings. Build. Environ. 1997, 32, 331-339. [CrossRef]

105. Jedrzejuk, H.; Marks, W. Optimization of shape and functional structure of buildings as well as heat source utilisation example. Build. Environ. 2002, 37, 1249-1253. [CrossRef] 
106. Nuffida, N.E. On Architecture and Energy: The Concept of (Generating) form through Adaptation. Procedia Soc. Behav. Sci. 2015, 179, 154-164. [CrossRef]

107. Bellia, L.; Falco, F.D.; Minichiello, F. Effects of solar shading devices on energy requirements of standalone office buildings for Italian climates. Appl. Therm. Eng. 2013, 54, 190-201. [CrossRef]

108. Kim, J.T.; Kim, G. Advanced External Shading Device to Maximize Visual and View Performance. Indoor Built. Environ. 2010, 19, 65-72.

109. Alzoubi, H.H.; Al-Zoubi, A.H. Assessment of building façade performance in terms of daylighting and the associated energy consumption in architectural spaces: Vertical and horizontal shading devices for southern exposure facades. Energy Convers. Manag. 2010, 51, 1592-1599. [CrossRef]

110. Mazzichi, F.; Manzan, M. Energy and Daylighting Interaction in Offices with Shading Devices. In Proceedings of the BSA 1st IBPSA Italy Conference, Bolzano, Italy, 30 January-1 February 2013.

111. Krstić-Furundžić, A.; Vujošević, M.; Petrovski, A. Energy and environmental performance of the office building facade scenarios. Energy 2019, 183, 437-447. [CrossRef]

112. Sherif, A.; Zafarany, A.E.; Arafa, R. External perforated window Solar Screens: The effect of screen depth and perforation ratio on energy performance in extreme desert environments. Energy Build. 2012, 52, 1-10. [CrossRef]

113. Sherif, A.; Zafarany, A.E.; Arafa, R. Evaluating the Energy Performance of External Perforated Solar Screens: Effect of Rotation and Aspect Ratio. In Proceedings of the Sustainable Buildings (SB13), Singapare, 9-10 September 2013.

114. Ho, M.C.; Chiang, C.M.; Chou, P.C.; Chang, K.F.; Lee, C.Y. Optimal sun-shading design for enhanced daylight illumination of subtropical classrooms. Energy Build. 2008, 40, 1844-1855. [CrossRef]

115. Lau, A.K.K.; Salleh, E.; Lim, C.H.; Sulaiman, M.Y. Potential of shading devices and glazing configurations on cooling energy savings for high-rise office buildings in hot-humid climates: The case of Malaysia. Int. J. Sustain. Built. Environ. 2016, 5, 387-399. [CrossRef]

116. Yassine, F.; Hijleh, B.A. The Effect of Shading Devices on the Energy Consumption of Buildings: A Study on an Office Building in Dubai. In Proceedings of the SB13 Dubai conference, Dubai, UAE, 8-10 December 2013; p. 149.

117. Ghosh, A.; Neogi, S. Effect of fenestration geometrical factors on building energy consumption and performance evaluation of a new external solar shading device in warm and humid climatic condition. Sol. Energy 2018, 169, 94-104. [CrossRef]

118. Hernández, F.F.; López, J.M.C.; Suárez, J.M.P.; Muriano, M.C.G.; Rueda, S.C. Effects of louvers shading devices on visual comfort and energy demand of an office building. A case of study. Energy Procedia 2017, 140, 207-216. [CrossRef]

119. Liu, S.; Kwok, Y.T.; Lau, K.K.L.; Chan, P.W.; Ng, E. Investigating the energy saving potential of applying shading panels on opaque façades: A case study for residential buildings in Hong Kong. Energy Build. 2019, 193, 78-91. [CrossRef]

120. Alshayeba, M.; Mohamed, H.; Chang, J.D. Energy Analysis of Health Center Facilities in Saudi Arabia: Influence of Building Orientation, Shading Devices, and Roof Solar Reflectance. Procedia Eng. 2015, 118, 827-832. [CrossRef]

121. Kasinalis, C.; Loonen, R.C.G.M.; Cóstola, D.; Hensen, J.L.M. Framework for assessing the performance potential of seasonally adaptable facades using multi-objective optimization. Energy Build. 2014, 79, 106-113. [CrossRef]

122. Ossen, D.R.; Ahmad, M.H.; Madros, N.H. Impact of Solar Shading Geometry on Building Energy Use in Hot Humid Climates with Special Reference to Malysia. In Proceedings of the SUSTAINABLE SYMBIOSIS, National Seminar on Energy in Buildings (NSEB2005), Subang Jaya, Malysia, 10-11 May 2005; pp. 1-10.

123. Wagdy, A.; Fathy, F. A parametric approach for achieving optimum daylighting performance through solar screens in desert climates. J. Build. Eng. 2015, 3, 155-170. [CrossRef]

124. Nielsen, M.V.; Svendsen, S.; Jensen, L.B. Quantifying the potential of automated dynamic solar shading in office buildings through integrated simulations of energy and daylight. Sol. Energy 2011, 85, 757-768. [CrossRef]

125. Eltaweel, A.; Su, Y. Controlling venetian blinds based on parametric design; via implementing Grasshopper's plugins: A case study of an office building in Cairo. Energy Build. 2017, 139, 31-43. [CrossRef] 
126. Eltaweel, A.; Su, Y. Using integrated parametric control to achieve better daylighting uniformity in an office room: A multi-Step comparison study. Energy Build. 2017, 152, 137-148. [CrossRef]

127. González, J.; Fiorito, F. Daylight Design of Office Buildings: Optimisation of External Solar Shadings by Using Combined Simulation Methods. Buildings 2015, 5, 560-580. [CrossRef]

128. Sghiouri, H.; Mezrhab, A.; Karkri, M.; Naji, H. Shading devices optimization to enhance thermal comfort and energy performance of a residential building in Morocco. J. Build. Eng. 2018, 18, 292-302. [CrossRef]

129. Manzan, M.; Pinto, F. Genetic Optimization of External Shading Devices. In Proceedings of the 11th International IBPSA Conference, Glasgow, Scotland, UK, 27-30 July 2009; pp. 180-187.

130. Manzan, M. Genetic optimization of external fixed shading devices. Energy Build. 2014, 72, 431-440. [CrossRef]

131. Kirimtata, A.; Krejcar, O.; Ekici, B.; Tasgetiren, M.F. Multi-objective energy and daylight optimization of amorphous shading devices in buildings. Sol. Energy 2019, 185, 100-111. [CrossRef]

132. Khoroshiltseva, M.; Slanzi, D.; Poli, I. A Pareto-based multi-objective optimization algorithm to design energy-efficient shading devices. Appl. Energy 2016, 184, 1400-1410. [CrossRef]

133. Shan, R. Optimization for Whole Building Energy Simulation Method in Façade Design. In Proceedings of the ASHRAE Winter Conference, New York, NY, USA, 18-24 January 2014.

134. Mahdavinejad, M.; Mohammadi, S. Parametric optimization of daylight and thermal performance through louvers in hot and dry of Tehran. J. Fundam. Appl. Sci. 2016, 8, 1221-1236. [CrossRef]

135. Sterk, T.D.E. Building upon Negroponte: A hybridized model of control suitable for responsive architecture. Autom. Constr. 2005, 14, 225-232. [CrossRef]

136. Cachat, E.T.; Lobaccaro, G.; Goia, F.; Chaudhary, G. A methodology to improve the performance of PV integrated shading devices using multi-objective optimization. Appl. Energy 2019, 247, 731-744. [CrossRef]

137. Ahmed, M.M.S.; Abdel-Rahman, A.K.; Bady, M.; Mahrous, E. The thermal performance of residential building integrated with adaptive kinetic shading system. Int. Energy J. 2016, 16, 97-106.

138. Adriaenssens, S.; Barbarigos, L.R.; Kilian, A.; Baverel, O.; Charpentier, V.; Horner, M.; Buzatu, D. Dialectic Form Finding of Passive and Adaptive Shading Enclosures. Energies 2014, 7, 5201-5220. [CrossRef]

139. Giovannini, L.; Verso, V.R.M.L.; Karamata, B.; Andersen, M. Lighting and energy performance of an adaptive shading and daylighting system for arid climates. Energy Procedia 2015, 78, 370-375. [CrossRef]

140. Manzana, M.; Padovana, R. Multi-criteria energy and daylighting optimization for an office with fixed and moveable shading devices. Adv. Build. Energy. Res. 2015, 9, 238-252. [CrossRef]

141. Manzan, M.; Clarich, A. FAST energy and daylight optimization of an office with fixed and movable shading devices. Build. Eng. 2017, 113, 175-184. [CrossRef]

142. Pesentia, M.; Masera, G.; Fiorito, F. Shaping an Origami shading device through visual and thermal simulations. Energy Procedia 2015, 78, 346-351. [CrossRef]

143. Nagy, Z.; Svetozarevic, B.; Jayathissa, P.; Begle, M.; Hofer, J.; Lydon, G.; Willmann, A.; Schlueter, A. The adaptive solar facade: From concept to prototypes. Front. Archit. Res. 2016, 5, 143-156. [CrossRef]

144. Al-Masrani, S.M.; Al-Obaidi, K.M.; Zalin, N.A.; Isma, M.I.A. Design optimisation of solar shading systems for tropical office buildings: Challenges and future trends. Sol. Energy 2018, 170, 849-872. [CrossRef]

145. Lee, E.S.; DiBartolomeo, L.; Selkowitz, S.E. Thermal and daylighting performance of an automated venetian blind and lighting system in a full-scale private office. Energy Build. 1998, 29, 47-63. [CrossRef]

146. Peters, B.; Peters, T. Computing the Environment: Digital Design Tools for Simulation and Visualisation of Sustainable Architecture; John Wiley \& Sons Ltd.: West Sussex, UK, 2018; pp. 6-22.

147. Terzidis, K. Algorithmic Architecture; Elsevier and Architectural Press: Burlington, VT, USA, 2006; pp. 65-100.

148. Matlab. Available online: http://www.mathworks.com/products/matlab/ (accessed on 18 November 2019).

149. Rhino. Robert McNeel \& Associates. Available online: http://www.rhino3d.com (accessed on 18 November 2019).

150. Grasshopper3d. Robert McNeel \& Associates. Available online: http://www.grasshopper3d.com (accessed on 18 November 2019).

151. Galapagos. Available online: https:/www.grasshopper3d.com/group/galapagos (accessed on 18 November 2019).

152. Ladybug Tools. Available online: https://www.ladybug.tools/ (accessed on 18 November 2019).

153. Gervásio, H.; Santos, P.; Martins, R.; Silva, L.S.D. A macro-component approach for the assessment of building sustainability in early stages of design. Build. Eng. 2014, 73, 256-270. [CrossRef] 
154. Turrin, M.; Buelow, P.V.; Stouffs, R. Design explorations of performance driven geometry in architectural design using parametric modeling and genetic algorithms. Adv. Eng. Inform. 2011, 25, 656-675. [CrossRef]

155. Lu, W.S.; Fung, A.; Peng, Y.; Liang, C.; Rowlinson, S. Cost-benefit analysis of Building Information Modeling implementation in building projects through demystification of time-effort distribution curves. Build. Eng. 2014, 82, 317-327. [CrossRef]

156. Kanters, J.; Horvat, M. The Design Process known as IDP: A Discussion. Energy Procedia 2012, 30, 1153-1162. [CrossRef]

157. Shaviv, E.; Kalay, Y.E.; Peleg, U.J. An integrated knowledge-based and procedural system for the design of energy conscious buildings. Autom. Constr. 1992, 1, 123-141. [CrossRef]

158. Gao, H.; Koch, C.; Wu, Y.P. Building information modelling based building energy modelling: A review. Appl. Energy 2019, 238, 320-343. [CrossRef]

159. Kilian, A. Design innovation through constraint modeling. Int. J. Archit. Comput. 2006, 4, 87-105. [CrossRef]

160. Aish, R.; Woodbury, R. Multi-Level Interaction in Parametric Design. In Proceedings of the 5th International Symposium, Frauenwörth Cloister, Germany, 22-24 August 2005; pp. 151-162.

161. Yan, D.; O’Brien, W.; Hong, T.Z.; Feng, X.H.; Gunay, H.B.; Tahmasebi, F.; Mahdavi, A. Occupant behavior modeling for building performance simulation: Current state and future challenges. Energy Build. 2015, 107, 264-278. [CrossRef]

162. Winkler, J.; Munk, J.; Woods, J. Effect of occupant behavior and air-conditioner controls on humidity in typical and high-efficiency homes. Energy Build. 2018, 165, 364-378. [CrossRef]

163. Pang, Z.H.; O'Neill, Z. Uncertainty quantification and sensitivity analysis of the domestic hot water usage in hotels. Appl. Energy 2018, 232, 424-442. [CrossRef]

164. Sadeghi, S.A.; Awalgaonkar, N.M.; Karav, P.; Bilionis, I. A Bayesian modeling approach of human interactions with shading and electric lighting systems in private offices. Energy Build. 2017, 134, 185-201. [CrossRef]

165. Woodbury, R.; Burrow, A.L. Whither design space? Ai. Edam. 2006, 20, 63-82. [CrossRef]

166. Cody, B. Form Follows Energy: Using Natural Forces to Maximize Performance; Birkhäuser: Basel, Belgium, 2017; p. 9.

167. American Institute of Architects' Energy Modeling Working Group. Architect's Guide to Integrating Energy Modeling in the Design Process. Available online: https://www.aia.org/resources/8056-architects-guide-tointegrating-energy-modeling (accessed on 18 November 2019).

168. Li, J.; Yu, Z.J.; Haghighatc, F.; Zhang, G.Q. Development and improvement of occupant behavior models towards realistic building performance simulation: A review. Sustain. Cities. Soc. 2019, 50, 101685. [CrossRef]

169. Leitão, A.; Santos, L.; Lopes, J. Programming Languages for Generative Design: A Comparative Study. Int. J. Archit. Comput. 2012, 10, 139-162. [CrossRef]

170. Abdelhameed, W. BIM in architecture curriculum: A case study. Archit. Sci. Rev. 2018, 61, 480-491. [CrossRef]

171. Bonenberg, W.; Kapliński, O. The Architect and the Paradigms of Sustainable Development: A Review of Dilemmas. Sustainability 2018, 10, 100. [CrossRef]

172. Ahmad, M.; Mourshed, M.; Mundow, D.; Sisinni, M.; Rezgui, Y. Building energy metering and environmental monitoring-A state-of-the-art review and directions for future research. Energy Build. 2016, 120, 85-102. [CrossRef]

173. Zhao, H.X.; Magoulès, F. A review on the prediction of building energy consumption. Renew. Sustain. Energy Rev. 2012, 16, 3586-3592. [CrossRef]

174. Stazi, F.; Naspi, F.; D'Orazio, M. A literature review on driving factors and contextual events influencing occupants' behaviours in buildings. Build. Environ. 2017, 118, 40-66. [CrossRef]

175. Jones, M. Pushing the Envelope: Innovation and Collaboration at Bloomberg's New European Headquarters. Archit. Des. 2019, 89, 76-81. [CrossRef]

(C) 2020 by the authors. Licensee MDPI, Basel, Switzerland. This article is an open access article distributed under the terms and conditions of the Creative Commons Attribution (CC BY) license (http://creativecommons.org/licenses/by/4.0/). 